\title{
FGF13 Is Required for Histamine-Induced Itch Sensation by Interaction with $\mathrm{Na}_{\mathrm{V}} 1.7$
}

\author{
Fei Dong, ${ }^{1,3,4}$ Haixiang Shi, ${ }^{2,5}$ Liu Yang, ${ }^{1}$ Huaqing Xue, ${ }^{2}$ Manyi Wei, ${ }^{2}$ Yan-Qing Zhong, ${ }^{1,4}$ Lan Bao, ${ }^{2,5}$ and \\ Xu Zhang ${ }^{1,3,4,5}$ \\ ${ }^{1}$ Institute of Neuroscience and State Key Laboratory of Neuroscience, CAS Center for Excellence in Brain Science and Intelligence Technology, \\ Chinese Academy of Sciences, Shanghai, 200031, China, ${ }^{2}$ State Key Laboratory of Cell Biology, CAS Center for Excellence in Molecular Cell Science/ \\ Shanghai Institute of Biochemistry and Cell Biology, Chinese Academy of Sciences, Shanghai, 200031, China, ${ }^{3}$ Institute of Brain-Intelligence Science \\ and Technology, Zhangjiang Lab; Shanghai Center for Brain Science and Brain-Inspired Intelligence, Research Unit of Pain, Chinese Academy of \\ Medical Sciences, Shanghai, 201210, China, ${ }^{4}$ Shanghai Clinical Research Center, Chinese Academy of Sciences/Xu-Hui Central Hospital, Shanghai, \\ 200031, China, and ${ }^{5}$ School of Life Science and Technology, ShanghaiTech University, Shanghai, 201210, China
}

Itch can be induced by activation of small-diameter DRG neurons, which express abundant intracellular fibroblast growth factor 13 (FGF13). Although FGF13 is revealed to be essential for heat nociception, its role in mediating itch remains to be investigated. Here, we reported that loss of FGF13 in mouse DRG neurons impaired the histamine-induced scratching behavior. Calcium imaging showed that the percentage of histamine-responsive DRG neurons was largely decreased in FGF13-deficient mice; and consistently, electrophysiological recording exhibited that histamine failed to evoke action potential firing in most DRG neurons from these mice. Given that the reduced histamine-evoked neuronal response was caused by knockdown of FGF13 but not by FGF13A deficiency, FGF13B was supposed to mediate this process. Furthermore, overexpression of histamine Type 1 receptor H1R, but not H2R, H3R, nor H4R, increased the percentage of histamine-responsive DRG neurons, and the scratching behavior in FGF13-deficient mice was highly reduced by selective activation of H1R, suggesting that H1R is mainly required for FGF13-mediated neuronal response and scratching behavior induced by histamine. However, overexpression of H1R failed to rescue the histamine-evoked neuronal response in FGF13-deficient mice. Histamine enhanced the FGF13 interaction with $\mathrm{Na}_{\mathrm{V}}$ 1.7. Disruption of this interaction by a membrane-permeable competitive peptide, GST-Flag-Na ${ }_{V}$ 1.7CT-TAT, reduced the percentage of histamine-responsive DRG neurons, and impaired the histamine-induced scratching, indicating that the FGF13/ $\mathrm{Na}_{\mathrm{v}} 1.7$ interaction is a key molecular determinant in the histamine-induced itch sensation. Therefore, our study reveals a novel role of FGF13 in mediating itch sensation via the interaction of $\mathrm{Na}_{\mathrm{V}} 1.7$ in the peripheral nervous system.

Key words: DRG; fibroblast growth factor 13; histamine; itch sensation; sodium channel

Significance Statement

Scratching induced by itch brings serious tissue damage in chronic itchy diseases, and targeting itch-sensing molecules is crucial for its therapeutic intervention. Here, we reveal that FGF13 is required for the neuronal excitation and scratching behavior induced by histamine. We further provide the evidence that the histamine-evoked neuronal response is mainly mediated by histamine Type 1 receptor H1R, and is largely attenuated in FGF13-deficent mice. Importantly, we identify that histamine enhances the FGF13/ $\mathrm{Na}_{\mathrm{V}} 1.7$ interaction, and disruption of this interaction reduces histamine-evoked neuronal excitation and highly impairs histamine-induced scratching behavior. Additionally, we also find that FGF13 is involved in 5-hydroxytryptamine-induced scratching behavior and hapten 1-fluoro-2,4-dinitrobenzene-induced chronic itch.

Received Mar. 12, 2020; revised 0ct. 20, 2020; accepted 0ct. 21, 2020.

Author contributions: F.D., L.B., and X.Z. designed research; F.D., H.S., L.Y., H.X., M.W., and Y.-Q.Z. performed research; F.D. analyzed data; F.D. wrote the first draft of the paper; F.D., L.B., and X.Z. edited the paper; F.D., L.B., and X.Z. wrote the paper.

The authors declare no competing financial interests.

This work was supported by National Natural Science Foundation of China 31700901 and 31671058, Strategic Priority Research Program (B) of Chinese Academy of Sciences XDB39000000, Key Research Program of Frontier Sciences QYZDY-SSW-SMCO07, Chinese Academy of Sciences, Science and Technology Commission of Shanghai Municipality,
China 18JC1420301, and CAMS Innovation Fund for Medical Sciences 2019-12M-5-082. The funders had no role in study design, data collection and analysis, decision to publish, or preparation of the manuscript. We thank Dr. Yan-Gang Sun and Dr. Qingjian Han for help with the scratching behavior test.

Correspondence should be addressed to Xu Zhang at xu.zhang@ion.ac.cn or Lan Bao at baolan@sibcb. ac.cn.

https://doi.org/10.1523/JNEUROSCI.0599-20.2020

Copyright $\odot 2020$ the authors 


\section{Introduction}

Fibroblast growth factor 13 (FGF13) belongs to the intracellular nonsecretory form of FGFs. Different from other secretory FGFs that principally bind their receptors to elicit signal transduction, FGF13 is not released from cells because of lack of the signal sequence. FGF13 is expressed abundantly from development to adulthood in the neurons of DRG (Hartung et al., 1997; Li et al., 2002). Immunostaining showed that FGF13 was present in $>80 \%$ of small-diameter DRG neurons (L. Yang et al., 2017). Activation of small DRG neurons was found to generate multiple types of somatosensation, including pain and itch. Noxious stimuli (e.g., thermal, mechanical, and chemical) produce pain by activating cutaneous $\mathrm{A} \delta$ and $\mathrm{C}$ nociceptors, the peripheral terminals of small DRG neurons. Understanding of the FGF13 function in somatosensation came at first by our previous study using conditional FGF13-deficient mice in small DRG neurons, and these mice lost heat nociception but exhibited normal mechanical nociceptive responses in both the von Frey and RandallSelitto (tail clip) tests (L. Yang et al., 2017). Previous studies reported that intracellular FGFs are essential regulators of neuronal excitability, and the best characterized role for these FGFs is the interaction with voltage-gated sodium $\left(\mathrm{Na}_{\mathrm{V}}\right)$ channels to modulate the gating property and current density of sodium channels (C. J. Liu et al., 2001, 2003; Lou et al., 2005; Laezza et al., 2007, 2009; Yan et al., 2014; Bosch et al., 2015; L. Yang et al., 2017). Our previous study also revealed that FGF13 increased $\mathrm{Na}_{V} 1.7$ sodium currents and maintained the membrane localization of $\mathrm{Na}_{V} 1.7$ during noxious heat stimulation, enabling the sustained firing of action potentials (L. Yang et al., 2017).

In addition to pain, itch is also an aversive somatosensation to elicit desire and reflex to scratch. Ablation of the Mas-related G protein-coupled receptor A3 (MrgprA3)-positive DRG neurons reduced the scratching evoked by multiple pruritgens (Han et al., 2013). Neurons marked by natriuretic polypeptide b $(N p p b)$ are also required for itch responses (Mishra and Hoon, 2013). Our recent high-coverage single-cell RNA sequencing data reveal that itch-sensing neurons expressed $N p p b$ or MrgprA3 primarily belong to small DRG neurons that also contain transient receptor potential cation channel V1 (TRPV1) (Li et al., 2016). Selectively ablating TRPV $1^{+}$fibers from the DRG or in TRPV1 KO mice caused substantial deficits in scratching behaviors in response to pruritogens (Imamachi et al., 2009). Various peripheral itch-inducing stimuli generated within or administered to the skin are able to trigger itch, one of them being histamine. Histamine is the most studied pruritogen that serves as a classical inducer of itch and involved in the itch associated with urticaria, ocular, and nasal allergic reactions (Hide et al., 1993; Leonardi, 2002; Baroody et al., 2008). Studies reveal that histamine may play a key role in the pathogenesis of atopic dermatitis (Ikoma et al., 2003). Serotonin (5-hydroxytryptamine [5-HT]) and an antimalaria drug chloroquine (CQ) have also been shown to cause strong itch (Q. Liu et al., 2009; Dong and Dong, 2018). Both histamine and 5-HT are linked to allergic contact dermatitis, a common chronic skin disease that characterized by intense itch (Ikoma et al., 2003; Soga et al., 2007; Rausl et al., 2013). Since previous studies have shown that small DRG neurons are vital for itch detection, it is of significant interest to also explore the role of FGF13 in the itch sensation.

In the present study, we found that the depletion of FGF13 in $\mathrm{Na}_{\mathrm{V}} 1.8$-positive DRG neurons impaired the histamineinduced scratching. The histamine-evoked neuronal excitation was mainly mediated by histamine Type 1 receptor H1R and was largely attenuated in FGF13-deficient neurons. Importantly, histamine enhanced the interaction between FGF13 and $\mathrm{Na}_{\mathrm{V}} 1.7$, and disruption of this interaction reduced histamine-evoked neuronal excitation and impaired histamine-induced scratching. We also found that loss of FGF13 impaired scratching induced by 5 $\mathrm{HT}$, as well as in hapten 1-fluoro-2,4-dinitrobenzene (DNFB)induced chronic itch. Our study identifies FGF13 as a critical factor essential for regulating itch sensation in the peripheral nervous system.

\section{Materials and Methods}

Animals. All experiments were performed using protocols approved by the Committee of Use of Laboratory Animals and Common Facility, Institute of Neuroscience, Chinese Academy of Sciences. Male mice (2-4 months old) were raised together with littermates and housed in pathogen-free environment with a $12 \mathrm{~h}$ light $/ 12 \mathrm{~h}$ dark cycle at $22^{\circ} \mathrm{C}-26^{\circ}$ $\mathrm{C}$ and an ad libitum food and water supply.

The generation of conditional KO mice lacking FGF13 specifically in small DRG neurons was described previously (L. Yang et al., 2017). The Fgf13-loxP mice were obtained by flanking its exons 2 and 3, which encode the FGF13 core region with loxP sequences. The Fgf13 conditional KO mice were constructed by crossing Fgf13-loxP mice with bacterial artificial chromosome transgenic mice expressing Cre recombinase controlled by promoter elements of the $\mathrm{Na}_{\mathrm{V}} 1.8$ gene (SNS-Cre), which is mainly expressed in small DRG neurons. This gene deletion mediated by SNS-Cre was started at the perinatal stage, thereby minimizing the risk of developmental defects. The KO mice were viable and fertile, and did not exhibit visible abnormalities. Our experiments were performed with Fgfl3 KO mice $\left(F g f 13^{-/ Y}\right)$ and control Fgf13-loxP mice $\left(F g f 13^{\mathrm{F} / \mathrm{Y}}\right)$.

Itch behavioral test. Before experiments, $\mathrm{Fg} f 13^{\mathrm{F} / \mathrm{Y}}$ and $\mathrm{Fgfl} 3^{-\mathrm{Y}}$ mice were given $30 \mathrm{~min}$ to acclimate to the test chamber before treatment. Mice were then briefly removed from the chamber and given intradermal injection at the back neck with pruritic compound at a volume of $50 \mu \mathrm{l}$. Hindlimb scratching behavior directed toward the injection site was observed for $30 \mathrm{~min}$ at $5 \mathrm{~min}$ intervals. A bout of scratching was defined as a lifting of the hindlimb directed at the area of the injection site and then a replacing of the limb back to the floor, regardless of how many scratching strokes taken place between those two movements. Scratching behavior was qualified by counting the number of scratching bouts over the $30 \mathrm{~min}$ observation period. For intradermal injection, the following drug was dissolved in sterile saline and administered at a volume of $50 \mu \mathrm{l}$ : histamine $(500 \mu \mathrm{g} / 50 \mu \mathrm{l}), 5-\mathrm{HT}(10 \mu \mathrm{g} / 50 \mu \mathrm{l})$, CQ $(200 \mu \mathrm{g} /$ $50 \mu \mathrm{l})$, or agonists for histamine receptors: H1R agonist HTMT $(50 \mu \mathrm{g} /$ $50 \mu \mathrm{l}), \mathrm{H} 2 \mathrm{R}$ agonist dimaprit $(50 \mu \mathrm{g} / 50 \mu \mathrm{l}), \mathrm{H} 3 \mathrm{R}$ agonist immethridine $(160 \mu \mathrm{g} / 50 \mu \mathrm{l})$, or $\mathrm{H} 3 \mathrm{R}$ antagonist H4R agonist clobenpropit $(30 \mu \mathrm{g} /$ $50 \mu \mathrm{l})$. To test the role of $\mathrm{FGF} 13 / \mathrm{Na}_{\mathrm{V}} 1.7$ complex in the histamineinduced itch, GST-Flag-Na 1 1.7CT-TAT $\left(\mathrm{Na}_{\mathrm{V}} 1.7-\mathrm{TAT}\right)$ was used for the disruption of FGF13/ $\mathrm{Na}_{V} 1.7$ interaction. The same volume with $60 \mathrm{mg} /$ $\mathrm{kg} \mathrm{Na}$ 1.7CT-TAT, $60 \mathrm{mg} / \mathrm{kg}$ GST-Flag-TAT, or vehicle was injected intraperitoneally into C57BL/6J mice each hour for 4 times, and followed by recording the histamine-induced scratching behavior.

Nocifensive behavior. Capsaicin-induced flinching behavior was performed by intraplantar injection of $10 \mu \mathrm{l}$ fresh-made $0.1 \%$ capsaicin solution $(0.5 \%$ capsaicin stock solution: Tween-80: saline $=2: 1: 7)$ under the dorsal surface of the hind paw. Allyl isothiocyanate (AITC)-induced flinching behavior was conducted by intraplantar injection of $10 \mu \mathrm{l}$ fresh-made $0.2 \%$ AITC solution (10\% AITC stock solution: DMSO: saline $=2: 10: 88)$. The licking and/or lifting of the injected paw were deemed as an indicator of the flinching behavior. The recording was observed for $5 \mathrm{~min}$ with capsaicin and for $30 \mathrm{~min}$ with AITC immediately after the injection.

Chronic itch. DNFB is widely used to induce allergic dermatitis in mouse models (Jin et al., 2009). The allergic contact dermatitis model of chronic itch was applying DNFB onto the back skin. In brief, DNFB dissolved in acetone and olive oil mixture (4:1) was used for sensitization and challenge. The surface of abdomen and the nape of neck were shaved $1 \mathrm{~d}$ before the sensitization. The sensitization was applied onto the abdomen area. Mice were intradermally injected with $50 \mu \mathrm{l}$ of $0.5 \%$ 
DNFB, and followed by topical application with $100 \mu \mathrm{l}$ of $0.5 \%$ DNFB. The challenge started $5 \mathrm{~d}$ later. Mice were painted with $50 \mu \mathrm{l}$ of $0.2 \%$ DNFB on the shaved neck area every other day for a week. Spontaneous scratching behaviors were videotaped for $1 \mathrm{~h}$ every $24 \mathrm{~h}$ after each challenge.

Plasmids. The expression constructs for H1R, H2R, and H4R were purchased (Origene), and H3R (NM_133849.3) was cloned from cDNA of mouse brain tissue and then cloned into the vector pCMV-mCherry. For the shRNA knockdown experiment, the sequences of shFGF13, shFGF13A, and shNC were designed as previously described (Wu et al., 2012). For the adeno-associated virus 9 (AAV9) constructs, these shRNAs were inserted into pAKD.CMV.bGlobin.eGFP.H1.shRNA vector (Genetic Reprogramming Platform, Institute of Neuroscience, CAS).

Cell culture and transfection. HEK293 cells were cultured in MEM supplemented with $10 \%$ FBS and antibiotics. The cells were transiently transfected with $1-2 \mu \mathrm{g}$ plasmids per $35 \mathrm{~mm}$ dish using Lipofectamine 2000 reagent (Invitrogen) and used for additional experiments after $24 \mathrm{~h}$.

DRGs from 2- to 4-month-old mice were carefully isolated and digested in oxygenated DMEM containing collagenase $(0.4 \mathrm{mg} / \mathrm{ml})$, tryp$\sin (1 \mathrm{mg} / \mathrm{ml})$, and DNase $(0.1 \mathrm{mg} / \mathrm{ml})$ for $30 \mathrm{~min}$ at $37^{\circ} \mathrm{C}$. For experiments without further treatment, dissociated cells were plated directly onto the poly-D-lysine-coated glass coverslips after gentle trituration in DMEM/F12 (1:1) medium supplemented with $100 \mathrm{U} / \mathrm{ml}$ penicillin, $0.1 \mathrm{mg} / \mathrm{ml}$ streptomycin, and $10 \%$ FBS. For the H1R, H2R, H3R, or H4R overexpression experiment, $5 \mu \mathrm{g}$ plasmids containing H1R were added directly to the suspension of neurons after isolation in Nucleofector buffer $(0.1 \mathrm{ml})$, and the mixture was electroporated in an Amaxa Nucleofector II using program O-003. Subsequently, neurons were washed by oxygenated DMEM/F12 medium and then plated onto coated coverslips. Electrophysiological recordings were performed $24 \mathrm{~h}$ after electro-transfection. For the shRNA knockdown experiment, dissociated cells plated onto coated coverslips were infected by adding $1 \mu \mathrm{l} \mathrm{AAV-}$ based shRNA (titer: $\sim 10^{8} \mathrm{vg} / \mathrm{ml}$ ) into the culture medium. The following experiments were performed after $7 \mathrm{~d}$ incubation.

Coimmunoprecipitation, immunoblotting and immunocytochemistry. Tissue samples or cultured neurons were homogenized in RIPA buffer ( $150 \mathrm{~mm} \mathrm{NaCl}, 30 \mathrm{~mm}$ HEPES, $10 \mathrm{~mm} \mathrm{NaF}, 1 \%$ Triton X-100, and $0.01 \%$ SDS) with protease inhibitors ( $1 \mathrm{mM}$ PMSF, $10 \mathrm{mg} / \mathrm{ml}$ aprotinin, $1 \mathrm{mg} / \mathrm{ml}$ pepstatin, and $1 \mathrm{mg} / \mathrm{ml}$ leupeptin). For coimmunoprecipitation, the tissue or cell supernatant was incubated with FGF13 antibody (Santa Cruz Biotechnology) overnight at $4^{\circ} \mathrm{C}$. The immunoprecipitates and $5 \%-$ $10 \%$ total lysates were analyzed by immunoblotting. For immunoblotting, the samples were separated by SDS-PAGE, and then transferred to nitrocellulose membrane. Primary antibody was applied overnight at $4^{\circ} \mathrm{C}$, and secondary antibody was applied for $1 \mathrm{~h}$ at room temperature. The specific protein bands were visualized with chemiluminescence. The primary antibodies included that against $\mathrm{Na}_{\mathrm{V}} 1.7$ (1:400, MABN41, Millipore), actin (1:6000, MAB1501, Chemicon), H1R (1:1000, self-made), FGF13 (1:500, sc-16811, Santa Cruz Biotechnology), and FGF13 (1:1000, HPA002809, Sigma Millipore). The specificity of self-made H1R antibody was conducted by preabsorption of antisera with $10 \mu \mathrm{M}$ antigen peptide into working antibody solution for $24 \mathrm{~h}$. The immunoreactive bands were quantified from at least three independent experiments using ImageJ 1.47 software (National Institutes of Health). The interaction between $\mathrm{Na}_{\mathrm{V}} 1.7$ and FGF13 before and after histamine stimulation was calculated using coimmunoprecipitated $\mathrm{Na}_{\mathrm{V}} 1.7$ compared with immunoprecipitated FGF13.

For immunocytochemistry, one coverslip was taken from the transfected HEK293 cells used for calcium imaging and fixed with 4\% PFA for $20 \mathrm{~min}$ at $4^{\circ} \mathrm{C}$. The coverslips were mounted and scanned using a TCS SP8 confocal microscope (Leica Microsystems).

Electrophysiological recording. Patch pipette with 3-5 $\mathrm{m} \Omega$ resistance was filled with solution containing $140 \mathrm{~mm} \mathrm{KCl}, 0.5 \mathrm{~mm}$ EGTA, $5 \mathrm{~mm}$ HEPES, and $3 \mathrm{~mm} \mathrm{Mg-ATP}$, adjusted to $\mathrm{pH} 7.3$ with $\mathrm{KOH}$. The extracellular solution (ECS) contained $140 \mathrm{~mm} \mathrm{NaCl}, 3 \mathrm{~mm} \mathrm{KCl}, 2 \mathrm{~mm} \mathrm{CaCl}$, $2 \mathrm{mM} \mathrm{MgCl}_{2}$, and $10 \mathrm{~mm}$ HEPES, adjusted to $\mathrm{pH} 7.3$ with $\mathrm{NaOH}$. Whole-cell current-clamp recording was conducted with an AxonPatch700B amplifier in a voltage-clamp mode with a holding potential of
$-70 \mathrm{mV}$ and then performed after switching to a current-clamp mode. Only the cells with stable resting potential $<-40 \mathrm{mV}$ were used in this study. The data were filtered at $5 \mathrm{kHz}$ and digitized at $20 \mathrm{kHz}$. The recording chamber was continuously perfused with fresh ECS at a flow rate of $2 \mathrm{ml} / \mathrm{min}$.

Action potentials (APs) induced by histamine were recorded in a current-clamp mode at room temperature $\left(22^{\circ} \mathrm{C}-25^{\circ} \mathrm{C}\right)$. The neuron that could be evoked AP firing by histamine was considered as a histamineresponding neuron. To investigate FGF13 in histamine-evoked neuronal excitation, $1 \mathrm{~mm}$ histamine was applied for $10 \mathrm{~s}$ onto small DRG neurons cultured from $\mathrm{Fgfl} 13^{\mathrm{F} / \mathrm{Y}}$ or $\mathrm{Fg} / 13^{-/ \mathrm{Y}}$ mice after 30 s perfusion with ECS. The neuron was considered as a histamine-responding neuron if at least three APs could be evoked by $10 \mathrm{~s}$ histamine application. The same protocol was performed in neurons from C57BL/6J mice incubated with vehicle, $1 \mu \mathrm{m}$ TTX, and $10 \mathrm{~nm}$ Protoxin-II for at least $30 \mathrm{~min}$. The mCherry-expressing neuron was given $10 \mathrm{~s}$ puffing with $1 \mathrm{~mm}$ histamine to detect the AP firing after a $60 \mathrm{~s}$ perfusion by ECS. The drug treatment group was given $10 \mathrm{~s} 1 \mathrm{~mm}$ histamine after $60 \mathrm{~s}$ ECS perfusion and another $10 \mathrm{~s} 1 \mathrm{~mm}$ histamine after $3 \mathrm{~min} 1 \mu \mathrm{M}$ TTX or $10 \mathrm{~nm}$ Protoxin-II solution perfusion. The control group for drug treatment used $3 \mathrm{~min}$ ECS to replace the drug treatment. The spike number evoked by histamine was compared with which after drug treatment.

Calcium imaging. For calcium imaging, cultured neurons or HEK293 cells were loaded for at least $30 \mathrm{~min}$ in the dark with $10 \mu \mathrm{M}$ fura- $2 \mathrm{AM}$ at $4^{\circ} \mathrm{C}$ in ECS. Cells were imaged at 340 and $380 \mathrm{nM}$, and the ratio of fluorescent intensity at 340 versus $380 \mathrm{~nm}$ was calculated using MetaMorph software. Cells were identified as neurons by eliciting depolarization with $40 \mathrm{~mm} \mathrm{KCl}$ at the end of each experiment. Cells were deemed to be sensitive to an agonist if the average ratio during $10 \mathrm{~s}$ histamine application was $15 \%$ above baseline. The percentage of agonistresponding neurons was calculated from cells responded to $\mathrm{KCl}$. Cells were transfected with the plasmid expressing shFGF13 or shFGF13A and GFP, which could separately indicate the expression of shRNA. GFP has a major excitation peak at a wavelength of $395 \mathrm{~nm}$ and a minor one at $475 \mathrm{~nm}$. Its emission peak is at $509 \mathrm{~nm}$. The calcium dye fura- 2 AM has quite similar excitation peaks at 335-345 and 380-390 nm and emission peak at $475-535 \mathrm{~nm}$. The overlapped GFP caused a high background for fura- 2 AM signal. To avoid the interference of GFP signal, we have normalized fura-2 AM ratio to baseline ratio $\left[\mathrm{F}_{340} / \mathrm{F}_{380}=(\right.$ Ratio $) /\left(\right.$ Ratio $\left.\left._{\mathrm{t}=0}\right)\right]$ as a previous study (Wilson et al., 2011). To disrupt endogenous FGF13/Na 1.7 interaction, we incubated DRG neurons with $1 \mu \mathrm{M}$ GST-Flag-Nav $1.7 C T-T A T$ or control $1 \mu \mathrm{M}$ GST-Flag-TAT for $30 \mathrm{~min}$ before fura-2 AM loading.

Experimental design and statistical analysis. Data are presented as mean \pm SEM. Sample number $(n)$ values are indicated in the figure legends and in Results. Two groups were compared by a two-tailed, unpaired Student's $t$ test. Comparison between two groups with multiple times was performed by a two-way ANOVA with Bonferroni's post hoc test. Multiple groups were compared by a one-way ANOVA with Tukey's post hoc test. Statistical analysis was performed using PRISM (GraphPad Software). The difference was considered significant at $p<0.05$. All statistical analyses were two-tailed, $95 \%$ CI.

\section{Results}

\section{Loss of FGF13 in DRG neurons impairs histamine-induced scratching behavior}

To identify the involvement of FGF13 in itch sensation, we initially examined the change of scratching behavior in mice, whose FGF13 gene (Fgf13) was deleted in small DRG neurons by crossing homozygous Fgf13-flox mice with transgenic mice expressing SNS-Cre according to previous studies (Agarwal et al., 2004; L. Yang et al., 2017). Scratching behavior was assessed by intradermally injecting pruritogen into right side of the nape, and the number of bouts in right hind paw scratching directed toward the injection site was analyzed and binned every $5 \mathrm{~min}$. This experiment was conducted with control Fgf13-flox mice $\left(\mathrm{Fg} f 13^{\mathrm{F} / \mathrm{Y}}\right)$ and $\mathrm{Fgf13} \mathrm{KO}$ mice $\left(\mathrm{SNS}-\mathrm{Cre} / \mathrm{Fg} / 3^{\mathrm{F} / \mathrm{Y}} ; \mathrm{Fg} 13^{-/ \mathrm{Y}}\right)$. In response to 
A
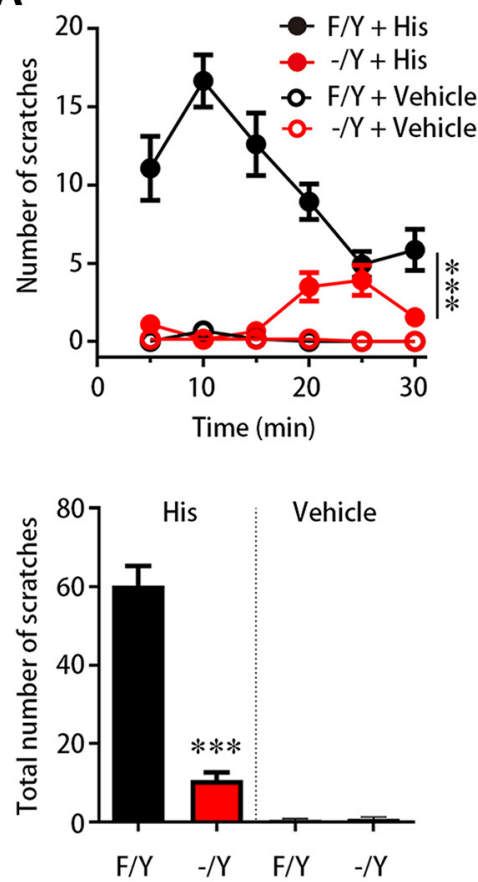

B

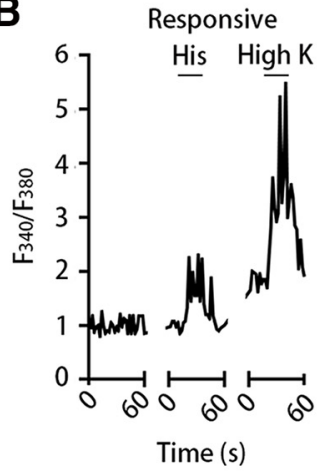

C

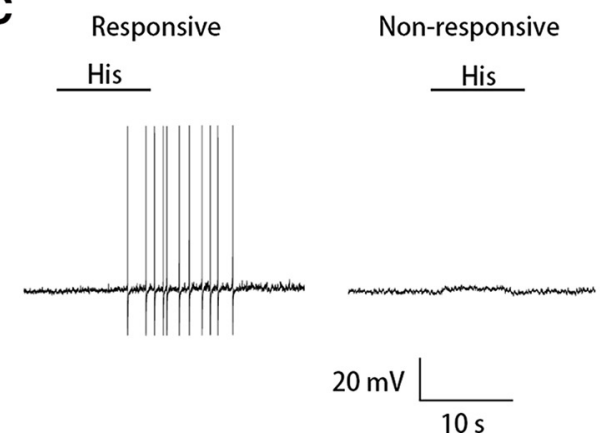

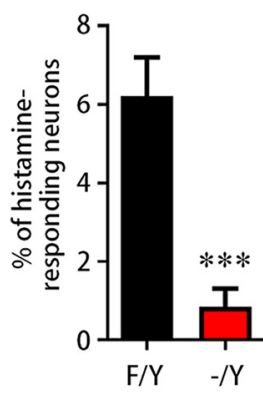
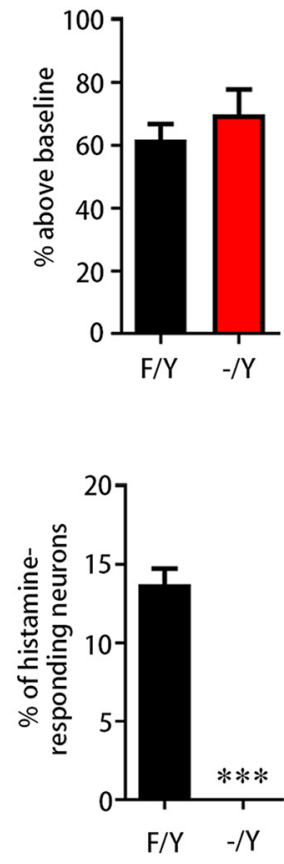

Figure 1. FGF13 is required for histamine-induced itch and neuronal response. $\boldsymbol{A}$, The behavior test showing altered scratching number in FGF13-deficient mice. The scratching number induced by intradermal injection of histamine $(500 \mu \mathrm{g} / 50 \mu \mathrm{l})$ in $\mathrm{Fgf13}{ }^{-N}$ mice $(n=28)$ was significantly decreased compared with that in Fgf $13^{\mathrm{FN}}$ mice $(n=31)$. The data were binned every $5 \mathrm{~min}$ (top) and analyzed during $30 \mathrm{~min}$ (bottom). Intradermal injection of vehicle barely induced scratching behavior in both $F g f 13^{F N}$ and $F g f 13^{-N}$ mice. $B$, Calcium imaging showing reduced percentage of histamine-responding neurons in $F g f 13^{-N}$ mice. Left, A representative trace was shown from a histamine-responding neuron in calcium imaging. Middle, The percentage of histamine-responding neurons was reduced in $F g f 13^{-N}$ mice ( $n=8$ from 1 or 2 mice each, 707 cells), compared with $F g f 13^{\mathrm{FN}}$ mice ( $n=8$ from 1 or 2 mice each, 850 cells). The magnitude of the $\mathrm{Ca}^{2+}$ response was similar in neurons from $\mathrm{Fgf13} 3^{\mathrm{FN}}$ (43 neurons) and $\mathrm{Fgf13} 3^{-N}$ mice (6 neurons) (right). C, Whole-cell patch-clamp recording showing failed AP firing in neurons from $\mathrm{Fgf7}{ }^{-N}$ mice ( $n=6$ mice, 43 cells), compared with Fgf1 $3^{\mathrm{FN}}$ mice ( $n=7$ mice, 53 cells). Left, Examples of a neuron elicited AP firing and a neuron failed to elicit APs on $1 \mathrm{~mm}$ histamine treatment were displayed. Data are mean \pm SEM. $* * * p<0.001$ for comparison between two curves (two-way ANOVA). $* * * p<0.001$ versus Fgf1 ${ }^{\mathrm{FN}}$ mice.

intradermal injection of $500 \mu \mathrm{g}$ histamine in $50 \mu \mathrm{l}$, control $\mathrm{Fg} f 13^{\mathrm{F} /}$ ${ }^{\mathrm{Y}}$ mice were observed with several bouts in the first $5 \mathrm{~min}$ and then reached a scratching peak within 10-15 min (Fig. 1A). Strikingly, the itch behavior induced by histamine was highly decreased in $\mathrm{Fgfl} 3^{-\mathrm{Y}}$ mice. Compared with $\mathrm{Fg} f 3^{\mathrm{F} / \mathrm{Y}}$ mice with high scratching response, $\mathrm{Fg} f 13^{-/ Y}$ mice displayed a limited number of scratches throughout $30 \mathrm{~min}$ of recording after intradermal injection of $500 \mu \mathrm{g} / 50 \mu \mathrm{l}$ histamine (Fig. $1 A ; F_{(1,285)}=97.280$, $p<0.0001)$. Since the mice injected with vehicle in both $\mathrm{Fg} f 13^{\mathrm{F} / \mathrm{Y}}$ $(0.6 \pm 0.3, n=7)$ and $F g f 13^{-/ Y}$ mice $(0.8 \pm 0.5, n=6)$ barely scratched $(t=0.481, \mathrm{df}=11, p=0.6400)$ for $30 \mathrm{~min}$, the delayed onset of histamine-induced scratch behavior in $\mathrm{Fg} 13^{-/ Y}$ mice observed between 20 and $30 \mathrm{~min}$ after injection might be the late response because of the off-target effect of histamine that activates mast cells or immune cells to elicit itch independent of direct activation to the receptor in neurons (Thurmond et al., 2008). It should be also noted that $\mathrm{Fg} / 3^{-/ \mathrm{Y}}$ mice exhibited the profound scratching deficit in total number of scratching bouts induced by histamine for $30 \mathrm{~min}$ (Fig. $1 A ; t=9.079, \mathrm{df}=35, p<0.0001$ ). The total number of scratching bouts induced by $500 \mu \mathrm{g}$ histamine was $60.1 \pm 5.1$ in $F g f 13^{\mathrm{F} / \mathrm{Y}}$ mice $(n=28)$ and $10.7 \pm 2.0$ in $\mathrm{Fg} f 13^{-/ \mathrm{Y}}$ mice $(n=31)$ (Fig. $1 A)$. These data indicate that the histamineinduced scratching behavior is impaired robustly in FGF13deficient mice.

FGF13 deficiency in DRG neurons displays the deficit of neuronal excitation induced by histamine

Since itch sensation results from a direct activation of DRG neurons by pruritogens, the behavioral deficit in $\mathrm{Fg} 13^{-/ Y}$ mice would be attributed to a loss of neuronal responsiveness in the DRG. To determine whether loss of FGF13 altered neuronal response, we first compared the change of histamine-evoked $\mathrm{Ca}^{2+}$ signals indicated by $\mathrm{F}_{340} / \mathrm{F}_{380}$ in cultured DRG neurons between $\mathrm{KO}$ $\mathrm{Fgfl} 3^{-/ \mathrm{Y}}$ mice and control $\mathrm{Fgfl} 3^{\mathrm{F} / \mathrm{Y}}$ littermates. Calcium imaging showed that the percentage of histamine-responding DRG neurons was largely decreased in $F g f 13^{-/ Y}$ mice $(t=5.695, \mathrm{df}=7$, $p=0.0007)$. In Fgf $13^{\mathrm{F} / \mathrm{Y}}$ mice, $1 \mathrm{~mm}$ histamine increased the cellular $\mathrm{Ca}^{2+}$ concentration in $6.2 \pm 1.0 \%$ neurons $(n=8,1$ or 2 mice each time, 850 cells) (Fig. $1 B$ ). However, only $0.9 \pm 0.5 \%$ neurons ( $n=8,1$ or 2 mice each time, 707 cells) responded to $1 \mathrm{~mm}$ histamine in $\mathrm{Fgfl} 3^{-/ \mathrm{Y}}$ mice (Fig. $1 B$ ). The magnitude of $\mathrm{Ca}^{2+}$ signals was not changed $(t=0.592, \mathrm{df}=47, p=0.5566)$ in the responsive neurons of $\mathrm{Fgfl} 3^{-/ \mathrm{Y}}$ mice $(70.0 \pm 8.0 \%, n=6$ cells) compared with that of $\mathrm{Fgfl} 13^{\mathrm{F} / \mathrm{Y}}$ mice $(61.8 \pm 5.0 \%, n=43$ cells) (Fig. $1 B$ ). Thus, the histamine-induced response requires the intact of FGF13 in DRG neurons.

To further probe the role of FGF13 in the pruritogen-induced neuronal excitability, we next performed the patch-clamp recording of AP firing in cultured DRG neurons from $\mathrm{Fg} 13^{\mathrm{F} / \mathrm{Y}}$ and $\mathrm{Fg} 13^{-/ Y}$ mice. Consistent with the result from $\mathrm{Ca}^{2+}$ imaging, the percentage of histamine-excited neurons was also dramatically reduced $(t=12.517, \mathrm{df}=11, p<0.0001)$. In $\mathrm{Fg} f 13^{\mathrm{F} / \mathrm{Y}}$ mice, $13.7 \pm$ $1.0 \%$ small DRG neurons ( $n=7$ mice, 53 cells) fired APs in response to $1 \mathrm{~mm}$ histamine (Fig. $1 C$ ). In contrast, all recorded small DRG neurons ( $n=6$ mice, 43 cells) cultured from $F g f 13^{-/ Y}$ mice failed to produce APs by histamine treatment (Fig. 1C). The percentage of histamine-responding neurons detected by electrophysiological recording in $\mathrm{Fgfl}^{\mathrm{F} / \mathrm{Y}}$ mice was higher than 

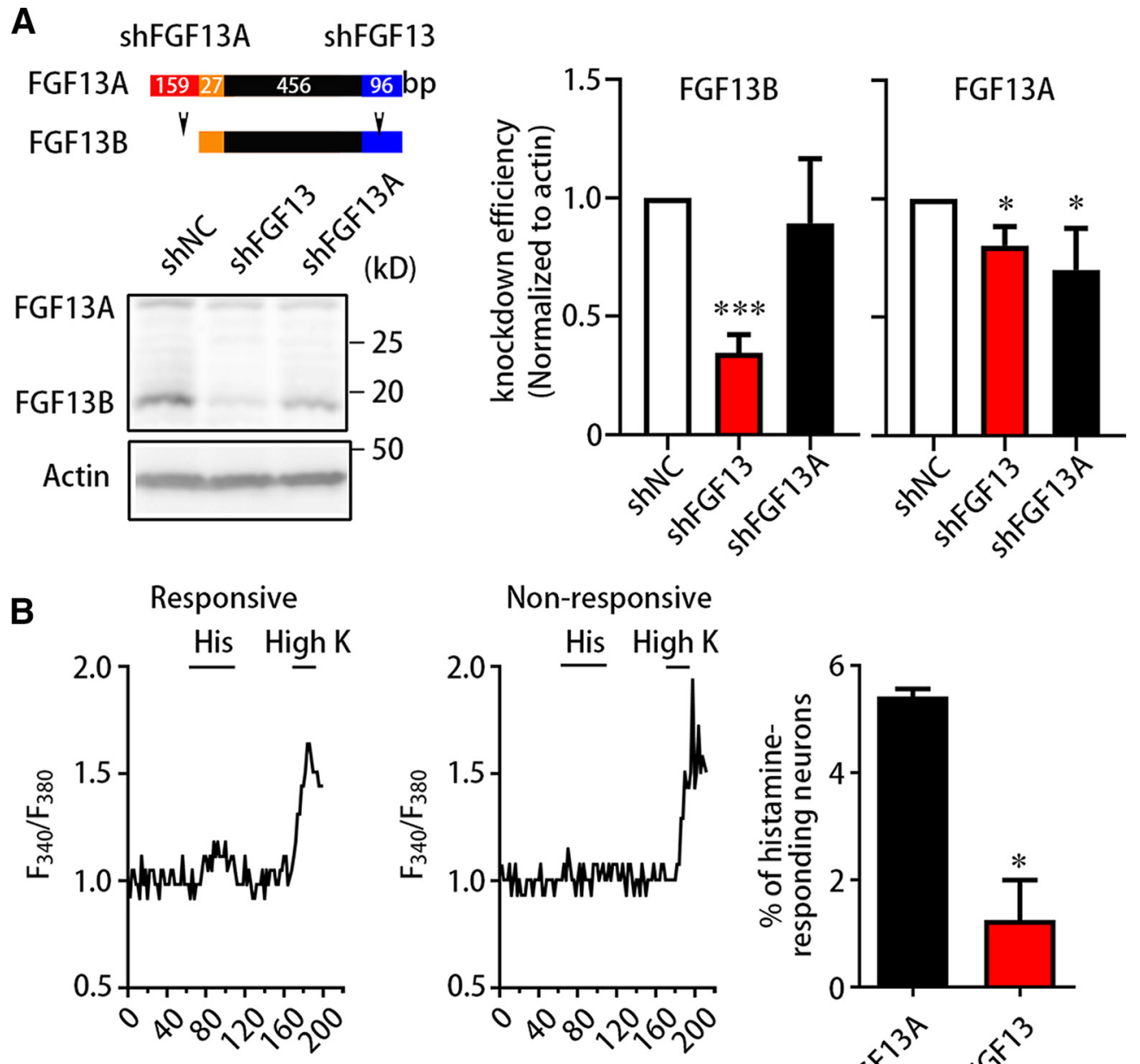

Time after perfusion (s)

Figure 2. FGF13B mediates the histamine-induced neuronal response. $A$, Immunoblotting showing shRNA-mediated knockdown of FGF13 isoform. Schematic diagram of shRNAs designed to target against FGF13A mRNA (shFGF13A) and FGF13A/B mRNA (shFGF13) (top left). Immunoblotting displayed that the FGF13B expression was significantly reduced in neurons treated with shFGF13, instead of shFGF13A and shNC. Data were quantified and plotted as normalized values versus FGF13B from neurons treated with shNC (right). The FGF13B level was largely dropped in neurons treated with shFGF13 but almost unaltered in neurons treated with shFGF13A, and the FGF13A level was reduced in neurons treated with both shFGF13 and shFGF13A. Data are mean \pm SEM. $* p<0.05 ; * * * p<0.001$; versus shNC. $\boldsymbol{B}$, Calcium imaging showing reduced percentage of histamine-responding neurons after knockdown of FGF13. Representative traces of calcium imaging were exhibited from histamine-responding neurons and histamine-nonresponding neurons (left) treated with shFGF13 or shFGF13A. The percentage of histamine-responding neurons was markedly reduced in neurons treated with shFGF13 ( $n=4$ from 1 or 2 mice each, 185 cells), compared with neurons treated with shFGF13A ( $n=4$ from 1 or 2 mice each, 277 cells) (right). Data are mean \pm SEM. $* p<0.05$ versus shFGF13A.

that detected by calcium imaging. This difference mainly resulted from the detected pool of neurons because small DRG neurons in patch-clamp recording has a much narrower range in cell sizes compared with all neurons of various sizes using calcium imaging. Together, these data indicate that FGF13 is required for histamine-evoked DRG neuronal response.

FGF13B mediates the histamine-induced neuronal response FGF13 has two major alternative splicing isoforms (FGF13A and FGF13B) in the mouse. FGF13A contains the nucleus localization signal, whereas FGF13B is distributed in the cytoplasm and contributes to dynamic signaling processes (Wu et al., 2012). To explore which isoform was involved in the histamine-induced itch, we performed calcium imaging on cultured DRG neurons transfected with AAV-expressing shFGF13 (targeting at FGF13 mRNA), shFGF13A (targeting at FGF13A mRNA), or shNC (negative control) for $7 \mathrm{~d}$. Immunoblotting detected that knockdown of FGF13, but not FGF13A, largely reduced the expression of FGF13B $\left(F_{(1.067,7.468)}=33.00, p=0.0005\right.$; Fig. $\left.2 A\right)$. The level of FGF13B was decreased to $34.6 \pm 2.9 \%$ by $\operatorname{shFGF13}(n=8)$. The level of FGF13A was also significantly reduced by knockdown of FGF13 or FGF13A $\left(F_{(1.341,4.024)}=9.812, p=0.0319\right)$ in cultured DRG neurons. Cultured DRG neurons transfected with shFGF13 showed a decrease in the percentage of histamineresponding neurons $(t=5.169, \mathrm{df}=3, p=0.0140)$. In the neurons transfected with shFGF13A, $1 \mathrm{~mm}$ histamine increased the cellular $\mathrm{Ca}^{2+}$ concentration in $5.4 \pm 0.1 \%$ cells $(n=4$ from 1 or 2 mice each, 277 cells), while only $1.3 \pm 0.8 \%$ neurons ( $n=4$ from 1 or 2 mice each, 185 cells) transfected with shFGF13 responded to histamine (Fig. $2 B$ ). Additionally, we excluded the possibility that AAV-mediated shRNA treatment may affect neurons in a sicken way. The amplitude above baseline of $\mathrm{KCl}$-responding neurons treated with shRNA $(205.4 \pm 6.2 \%)$ was similar to that from $F g f 13^{\mathrm{F} / \mathrm{Y}}$ $(260.8 \pm 18.4 \%)$ or $F g f 13^{-/ Y}(275.0 \pm 23.1 \%)$ mice. Meanwhile, the percentage of histamine-responding neurons treated with shFGF13A (5.4 \pm 0.1\%; Fig. $2 B$ ) was similar to that from $F g f 13^{\mathrm{F} / \mathrm{Y}}$ mice $(6.2 \pm 1.0 \%$; Fig. $1 B)$. Therefore, this result suggests that FGF13B is the isoform for FGF13 to mediate the histamineinduced neuronal response. 
H1R-mediated itch is impaired in FGF13deficient mice

Histamine receptors are required for the signaling in sensory neurons being activated directly by histamine. We first screened receptors of histamine in DRG neurons. Four known subtypes of histamine receptor, including H1R, H2R, H3R, and H4R, which belong to the GPCR superfamily, were identified previously. Using our recent data based on high-coverage single-cell RNA sequencing, $\mathrm{H} 1 \mathrm{R}$ and $\mathrm{H} 2 \mathrm{R}$ were highly expressed in Nppb-expressing C2 and MrgprA3-expressing C4 DRG neurons, and H3R was mainly expressed in $\mathrm{C} 3$, marked by the $\mathrm{TH}$, DRG neurons (Fig. 3A). Our previous study also reported the expression of itch-related molecules in C2 and C4 DRG neurons, suggesting an important role of these neurons in the itch (L. Yang et al., 2017). Activation of H1R and H4R as well as H3R inhibition on sensory neurons could increase the calcium influx in a subpopulation of these neurons (Rossbach et al., 2011). Other studies revealed that H4R, but not H2R and H3R, causes itch in mice in addition to H1R (Bell et al., 2004; Shim and Oh, 2008). To clarify the role of different receptors in response to histamine in DRG neurons, we performed whole-cell patch-clamp recording on cultured DRG neurons transfected with H1R-mCherry, H2RmCherry, H3R-mCherry, or H4R-mCherry. The $84.7 \pm 8.2 \%$ of neurons expressing H1RmCherry ( $n=6$ from 1 or 2 mice each, 36 cells) could be induced APs by $1 \mathrm{~mm}$ histamine, while the neurons expressing $\mathrm{H} 2 \mathrm{R}$ mCherry $(8.3 \pm 8.3 \%, n=4$ from 1 or 2 mice each, 14 cells), H3R-mCherry (11.4 $\pm 5.9 \%$, $n=3$ from 1 or 2 mice each, 23 cells), or H4RmCherry $(6.3 \pm 6.3 \%, n=4$ from 1 or 2 mice each, 19 cells) in response to $1 \mathrm{~mm}$ histamine displayed the equivalent percentage of neurons expressing control vector $(4.8 \pm 4.8 \%$, $n=3$ from 1 or 2 mice each, 17 cells) (Fig. $3 B$; $\left.F_{(4,15)}=26.00, p<0.0001\right)$. We performed corresponding agonists in DRG neurons expressing H2R-mCherry, H3R-mCherry, or H4R-mCherry. Over 60\% neurons expressing these receptors could reduce the resting membrane potential or induce APs (Fig. 3B), indicating that $\mathrm{H} 2 \mathrm{R}, \mathrm{H} 3 \mathrm{R}$, and $\mathrm{H} 4 \mathrm{R}$ constructs are successfully expressed. Thus, H1R is the main functional receptor mediating histamine-induced response in DRG neurons.

We further explored whether H1R was involved in the impairment of histamineinduced scratching behavior in $\mathrm{Fg} 13^{-/ \mathrm{Y}}$ mice. The behavioral test showed that $1 \mathrm{~mm}$ HTMT, an H1R agonist, induced 23.6 \pm 5.0 scratching bouts within $30 \mathrm{~min}$ in $\mathrm{Fg} f 13^{\mathrm{F} / \mathrm{Y}}$ mice $(n=8)$, while total bouts induced by HTMT dropped to $2.3 \pm 1.3$ in $F g f 13^{-/ Y}$ mice $(n=7)$ (Fig. $3 C$; $t=3.902, \mathrm{df}=13, p=0.0020)$. Intradermal injection of $4 \mathrm{~mm}$

A

B
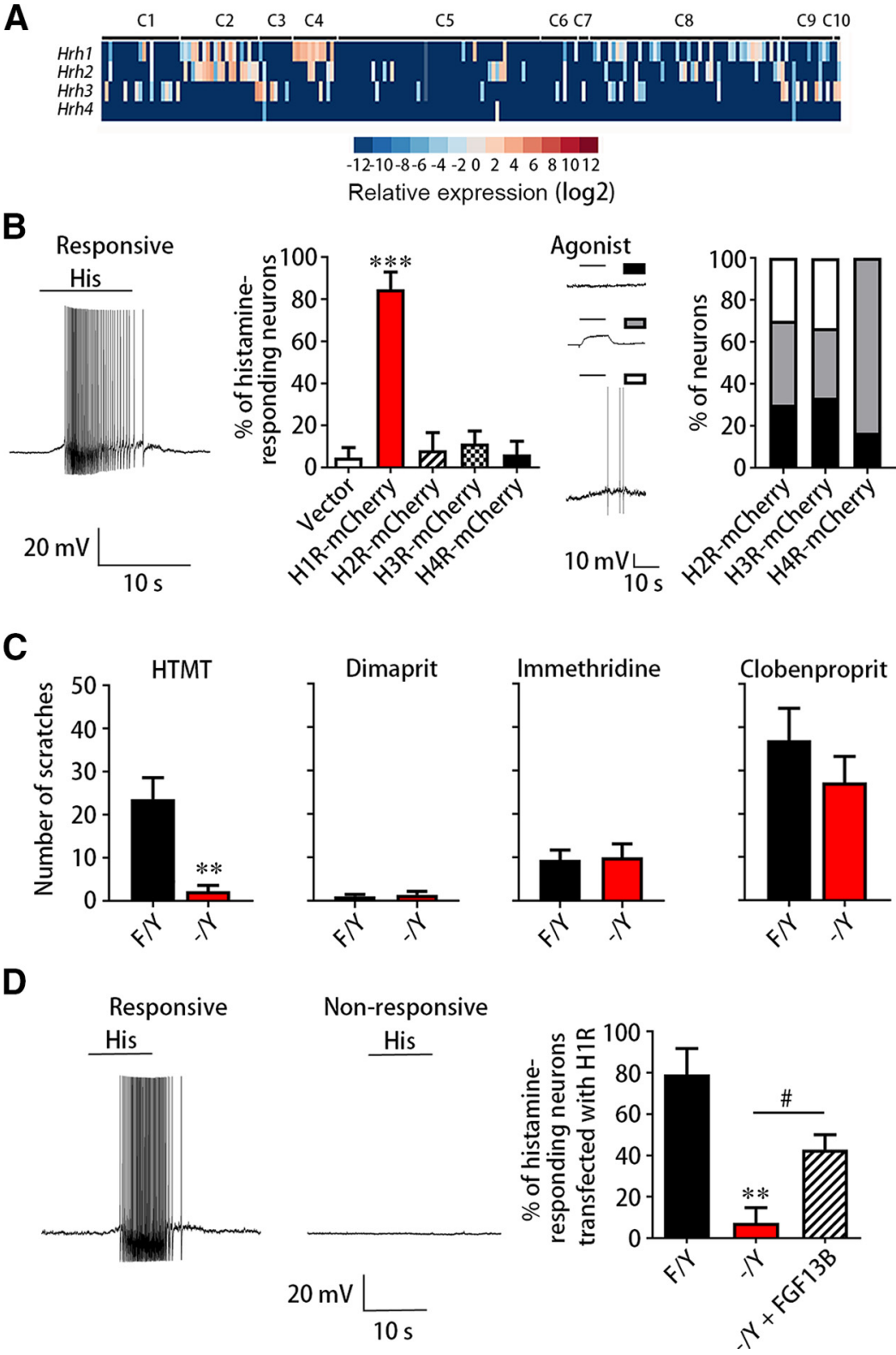

Figure 3. H1R is the main receptor for FGF13-mediated histamine signaling. $\boldsymbol{A}$, Single-cell RNA sequencing showing the expression profile of histamine receptors, H1R, H2R, H3R, and H4R in the DRG neuron types ( $11-\mathrm{C} 10)$ of mice. H1R and H2R were primarily expressed in $\mathrm{C} 2$ and $\mathrm{C} 4$ small DRG neurons, and H3R was mainly expressed in the $\mathrm{C} 3$ type of small DRG neurons. H4R was barely expressed in such neurons. $\boldsymbol{B}$, Whole-cell patch-clamp recording showing AP firing evoked by $1 \mathrm{~mm}$ histamine from neurons overexpressing $H 1 R, H 2 R, H 3 R$, H4R, or vector. Left, Representative AP firing from neurons responding to histamine. The percentage of neurons responding to histamine was the significantly highest when transfected with $\mathrm{H} 1 \mathrm{R}$ ( $n=6$ from 1 or 2 mice each, 36 cells) compared with vector ( $n=3$ from 1 or 2 mice each, 17 cells), H2R ( $n=4$ from 1 or 2 mice each, 14 cells), H3R ( $n=3$ from 1 or 2 mice each, 23 cells), and H4R ( $n=4$ from 1 or 2 mice each, 19 cells). The patchclamp recording showed that $>60 \%$ DRG neurons expressing H2R, H3R, or H4R responded to its agonist, suggesting normal function of these expressed receptors. Data are mean \pm SEM. $* * * p<0.001$ versus vector. $C$, The behavior test showing reduced scratching number induced by intradermal injection of H1R agonist HTMT within $30 \mathrm{~min}$ in Fgf1 $13^{-N}$ mice $(n=7) \mathrm{com}-$ pared with $\mathrm{Fgf13} 3^{\mathrm{FN}}$ mice $(n=8)$. However, the scratching number induced by H2R agonist Dimaprit, H3R agonist immethridine, or H3R antagonist H4R agonist clobenpropit was not significantly changed. Data are mean \pm SEM. $* * p<0.01$ versus $\mathrm{Fgfl}^{\mathrm{F} / \mathrm{K}}$ mice. $\boldsymbol{D}$, Whole-cell patch-clamp recording showing that the reduced percentage of neurons responding to histamine in $\mathrm{Fgfl}^{-N}{ }^{-N}$ mice (Fgf1 ${ }^{\mathrm{FN}}: n=4$ from 3 mice each, 24 cells; $\mathrm{Fgfl}^{-N}: n=4$ from 3 mice each, 17 cells) was rescued by FGF13B overexpression ( $n=3$ from 2 mice each, 21 cells). Representative AP firing from neurons responding to $1 \mathrm{~mm}$ histamine was shown (left). Data are mean \pm SEM. $* * p<0.01$ versus Fgf1 ${ }^{\mathrm{FN}}$ mice. ${ }^{\#} p<0.05$ versus $\mathrm{Fgf13} 3^{-N}$ mice.

dimaprit (H2R agonist), $10 \mathrm{~mm}$ immethridine (a potent H3R agonist), or $1.2 \mathrm{~mm}$ clobenpropit (H3R antagonist, H4R agonist) were also observed in $\mathrm{Fg} 13^{-/ \mathrm{Y}}$ mice. H2R agonist dimaprit barely induced scratching behavior. In contrast to H1R agonist HTMT, 

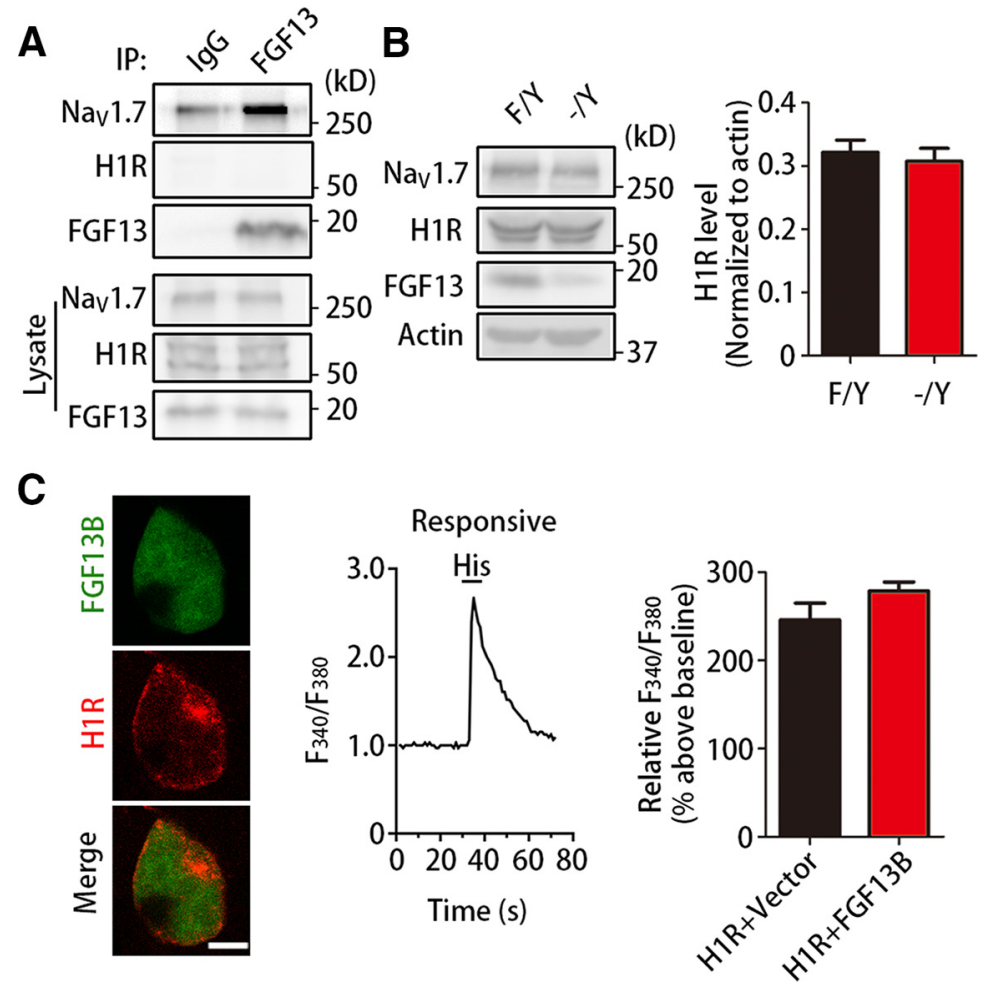

Figure 4. FGF13 does not physically and functionally affect H1R. A, Immunoblots showing that FGF13 barely interacted with H1R. Coimmunoprecipitation was performed with protein extracts from DRGs using FGF13 antibody and control $\operatorname{lgG}(n=3)$. $\boldsymbol{B}$, Immunoblots showing that the level of H1R was not significantly changed in cultured DRG neurons between $\mathrm{Fgfl}^{\mathrm{FN}}$ and $\mathrm{Fgf1} 3^{-\mathrm{N}}$ mice $(n=5)$. C, Calcium imaging showing that the increased $\mathrm{Ca}^{2+}$ signals were not significantly larger in HEK293 cells coexpressing H1R with FGF13B ( $n=4,178$ cells) than that coexpressing H1R with vector ( $n=4,220$ cells). Left, Representative images of a HEK293 cell coexpressing FGF13B-IRES-EGFP (green) and H1R-mCherry (red) were shown. Middle, Representative trace from an H1R-expressing HEK293 cell responding to histamine was measured in calcium imaging. Scale bar, $10 \mu \mathrm{m}$. Data are mean \pm SEM.

the scratching behavior did not display differently between $\mathrm{Fg} f 13^{\mathrm{F} / \mathrm{Y}}$ and $\mathrm{Fg} 13^{-/ \mathrm{Y}}$ mice induced by immethridine (Fig. $3 \mathrm{C} ; \mathrm{Fg} 13^{\mathrm{F} / \mathrm{Y}}$ : $9.4 \pm 2.3, n=8 ; \mathrm{Fg} 13^{-/ \mathrm{Y}}: 10 \pm 3.1, n=7, t=0.164, \mathrm{df}=13, p=$ 0.8700 ) and clobenpropit (Fig. $3 C ; F g f 13^{\mathrm{F} / \mathrm{Y}}: 37.0 \pm 7.5, n=9$; $\left.F g f 13^{-/ Y}: 27.2 \pm 4.7, n=9, t=1.028, \mathrm{df}=16, p=0.3200\right)$. Moreover, whole-cell patch-clamp recording detected that the cultured FGF13-deficient DRG neurons expressing H1R-mCherry almost lost ability $(t=4.477, \mathrm{df}=5, p=0.0065)$ to respond to $1 \mathrm{~mm}$ histamine $\left(79.2 \pm 12.5 \%\right.$ for $F g f 13^{\mathrm{F} / \mathrm{Y}}$ mice, $n=4$ from 3 mice each, 24 cells and $7.4 \pm 7.4 \%$ for $F g f 13^{-Y}$ mice, $n=4$ from 3 mice each, 17 cells; Fig. 3D). After coexpressing H1R-mCherry and FGF13BIRES-GFP, 42.9 $\pm 7.1 \%$ FGF13-deficient DRG neurons could be evoked AP firing by $1 \mathrm{~mm}$ histamine (Fig. $3 D ; n=3$ from 2 mice each, 21 cells; $t=3.451, \mathrm{df}=4, p=0.0300$ ). However, because of the lower transfection efficiency of FGF13B in DRG neurons, the percentage of histamine-responding neurons was not rescued to the level in DRG neurons only expressing H1R-mCherry from $\mathrm{Fg} f 13^{\mathrm{F} / \mathrm{Y}}$ mice. Together, these data suggest that loss of FGF13 impairs H1Rmediated itch induced by histamine.

FGF13 does not physically and functionally affect H1R Since H1R-mediated itch was impaired in $\mathrm{Fgfl}^{-/ \mathrm{Y}}$ mice, we wondered whether FGF13 functioned through its interaction with H1R to affect the histamine-evoked neuronal excitation. Coimmunoprecipitation was performed to evaluate a possibility of the interaction between FGF13 and H1R in the DRG. Indeed,
FGF13 interacted with $\mathrm{Na}_{\mathrm{v}} 1.7$ as previously reported (L. Yang et al., 2017) but barely with H1R in DRGs (Fig. 4A). Immunoblotting of cultured DRG neurons detected that, in $\mathrm{Fg} f 13^{-/ \mathrm{Y}}$ mice, the level of H1R was not altered $(t=0.657, \mathrm{df}=4, p=0.5473)$ and the amount of $\mathrm{Na}_{\mathrm{V}} 1.7$ was also unchanged (Fig. $4 B$ ) as our previous report (L. Yang et al., 2017). To detect whether FGF13 functionally coupled to H1R, we examined the change of cellular $\mathrm{Ca}^{2+}$ signals evoked by $1 \mathrm{~mm}$ histamine in HEK293 cells coexpressing FGF13B-IRES-GFP and H1R-mCherry. In comparison with the control cells only expressing H1R, the magnitude of histamine-evoked $\mathrm{Ca}^{2+}$ signals was not significantly changed $(t=3.060, \mathrm{df}=3, p=0.0550)$ in cells coexpressing H1R with FGF13B (H1R and vector: $2.5 \pm 0.2, n=4,220$ cells; H1R and FGF13B: $2.8 \pm 0.1$, $n=4,178$ cells) (Fig. 4C). Therefore, FGF13 does not directly regulate $\mathrm{H} 1 \mathrm{R}$.

\section{FGF13/Na 1.7 acts as the key mediator for histamine-induced itch}

Our previous study reveals that FGF13 increases the current density of $\mathrm{Na}_{\mathrm{V}} 1.7$ and maintains the excitability of small DRG neurons (L. Yang et al., 2017). Patients carrying a variant in SCN9A gene encoding $\mathrm{Na}_{\mathrm{V}} 1.7$ experience paroxysmal itch (Devigili et al., 2014). Previous reports provide evidence in mice showing that blocking $\mathrm{Na}_{\mathrm{V}} 1.7$ by selective antagonists inhibits the histamine-induced scratching behavior, as well as evoked neuronal excitability (Marx et al., 2016; Graceffa et al., 2017; Kornecook et al., 2017; Zhang et al., 2019; Chandra et al., 2020). First, we confirmed the role of $\mathrm{Na}_{\mathrm{V}} 1.7$ in the histamine signaling in DRG neurons. Compared with the control $(16.2 \pm 3.2 \%, n=3$, 31 cells), small DRG neurons incubated with $1 \mu \mathrm{M}$ TTX ( $0 \pm 0 \%, n=3,29$ cells) for at least $30 \mathrm{~min}$ failed to evoke AP firing (Fig. $5 A ; t=5.024$, df $=4$, $p=0.0070)$, and similar reduction was also found in neurons incubated with 10 nм Protoxin-II (2.6 $\pm 2.6 \%, n=3,32$ cells), a selective $\mathrm{Na}_{\mathrm{V}} 1.7$ blocker, for at least $30 \mathrm{~min}$ (Fig. 5A; $t=3.312, \mathrm{df}=4, p=0.0300)$. Then, we detected whether $\mathrm{Na}_{\mathrm{V}} 1.7$ was also required for H1R-mediated neuronal activation evoked by histamine. Typically, whole-cell patch-clamp recording showed that the histamine-induced APs in neurons expressing H1R-mCherry was dramatically reduced after applying either $1 \mu \mathrm{M}$ TTX $(30.4 \pm 8.8 \%, n=17$ cells; $t=7.951$, $\mathrm{df}=16, p<0.0001, n=17)$ or $10 \mathrm{~nm}$ Protoxin-II $(40.8 \pm 12.0 \%$, $n=12$ cells; $t=4.913, \mathrm{df}=11, p=0.0005, n=12)$, but was not significantly changed after perfusing ECS (127.9 $\pm 29.5 \%, n=7$ cells; $t=0.9471, \mathrm{df}=7, p=0.3751$ ) (Fig. $5 B-D$ ). Thus, $\mathrm{Na}_{\mathrm{V}} 1.7$ is also critical for H1R-mediated histamine signaling.

Then, we detected whether the FGF13/ $\mathrm{Na}_{\mathrm{V}} 1.7$ complex was involved in histamine-induced neuronal response. Cultured DRG neurons were incubated with $1 \mathrm{~mm}$ histamine for $5 \mathrm{~min}$ and performed for the detection of interaction between FGF13 and $\mathrm{Na}_{V}$ 1.7. Coimmunoprecipitation showed that the association between FGF13 and $\mathrm{Na}_{\mathrm{V}} 1.7$ was significantly enhanced $(t=3.075, \mathrm{df}=5, p=0.0276)$ by $1 \mathrm{~mm}$ histamine treatment for $5 \mathrm{~min}$ (Fig. 6A). Moreover, we explored the functional contribution of FGF13/ $\mathrm{Na}_{\mathrm{V}} 1.7$ interaction to the histamine-evoked neuronal response. The calcium imaging in neurons treated with $\mathrm{Na}_{\mathrm{V}}$ 1.7CT-TAT showed that the percentage of histamineresponding neurons was largely reduced $(t=5.992, \mathrm{df}=3$, 


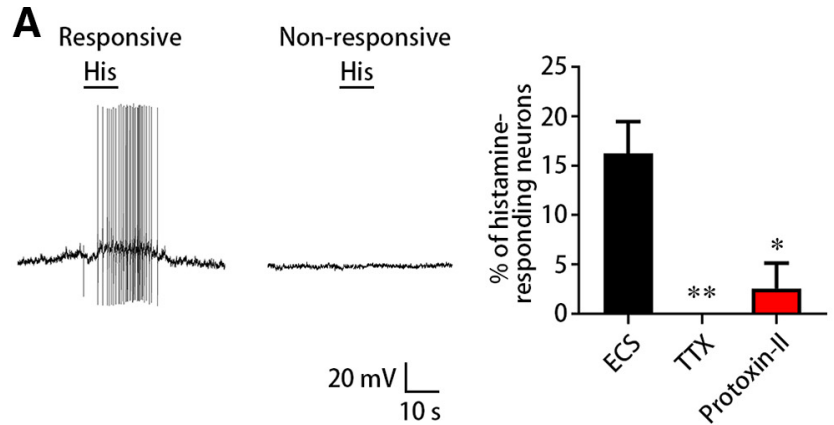

B

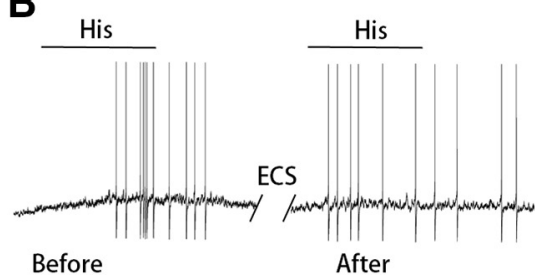

$20 \mathrm{mV}$

$10 \mathrm{~s}$

C
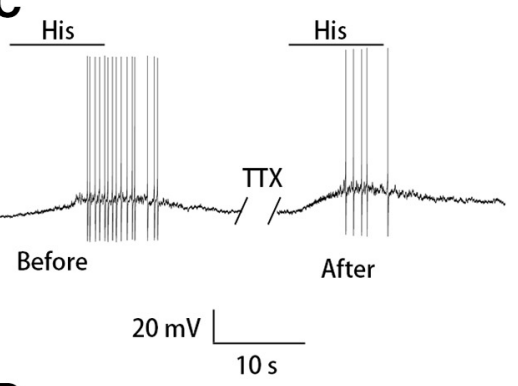

D

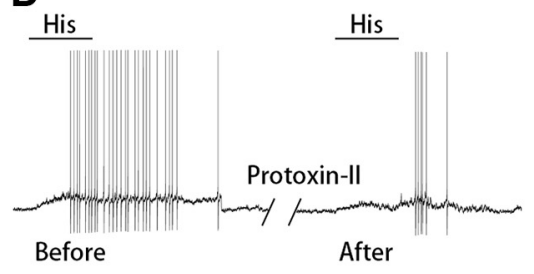

$20 \mathrm{mV}$

$10 \mathrm{~s}$

Figure 5. Nay 1.7 is crucial for the histamine-H1R signaling. A, Whole-cell patch-clamp recording showing the reduced percentage of histamine-responding neurons evoked by $1 \mathrm{~mm}$ histamine after the incubation at least for 30 min with TTX ( $n=3$, 29 cells) or Protoxin-II ( $n=3,32$ cells) compared with that with ECS ( $n=3,31$ cells). $\boldsymbol{B}-\mathbf{D}$, Whole-cell patch-clamp recording showing the change of AP firing in H1R-expressing neurons evoked by $1 \mathrm{~mm}$ histamine after 3 min ECS $(\boldsymbol{B})$, TTX $(\boldsymbol{C})$, or Protoxin-II $(\boldsymbol{D})$ perfusion. Representative AP firing from an H1R-expressing neuron responding to $1 \mathrm{~mm}$ histamine was shown (left). The neurons were still able to fire APs after 3 min ECS perfusion $(\boldsymbol{B}, n=7)$, but displayed a significantly smaller number of APs after $3 \min 1 \mu \mathrm{m} \operatorname{TTX}(\boldsymbol{C}, n=17)$ or $10 \mathrm{~nm}$ Protoxin-II $(\boldsymbol{D}, n=12)$ perfusion. The spike number evoked by histamine was calculated before and after histamine treatment; then data were normalized to that before histamine treatment. Data are mean \pm SEM. $* p<0.05 ; * * p<0.01$ versus ECS $(\boldsymbol{A})$, and $* * * p<0.001$ versus before $(\boldsymbol{C}, \boldsymbol{D})$.

$p=0.0093)$ after a $30 \mathrm{~min}$ incubation with $1 \mu \mathrm{M} \mathrm{Na} \mathrm{V}_{\mathrm{V}} 1.7 \mathrm{CT}$-TAT (3.8 $\pm 1.2 \%, n=4$ from 1 or 2 mice each, 428 cells), compared with control GST-Flag-TAT $(8.3 \pm 1.6 \%, n=4$ from 1 or 2 mice each, 509 cells) (Fig. $6 B$ ). The magnitude of $\mathrm{Ca}^{2+}$ signals was not changed $(t=0.324, \mathrm{df}=6, p=0.7600)$ in the responsive neurons from two groups (Fig. $6 B$ ). To test whether the peptide could directly affect $\mathrm{Na}_{\mathrm{V}} 1.7$ function, we recorded the sodium currents
A
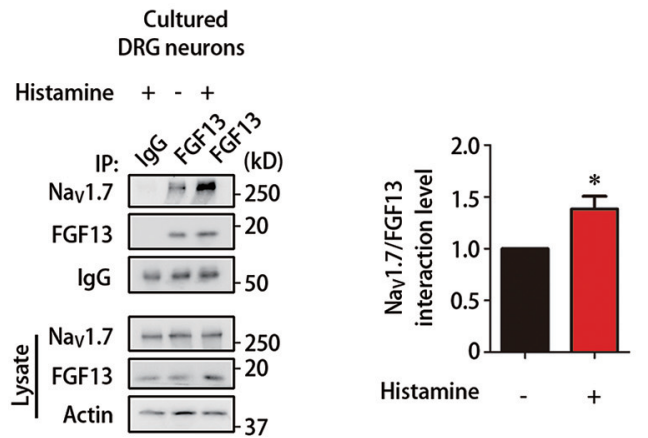

B
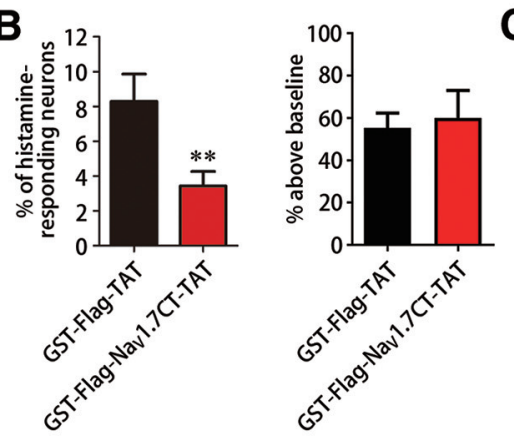

C
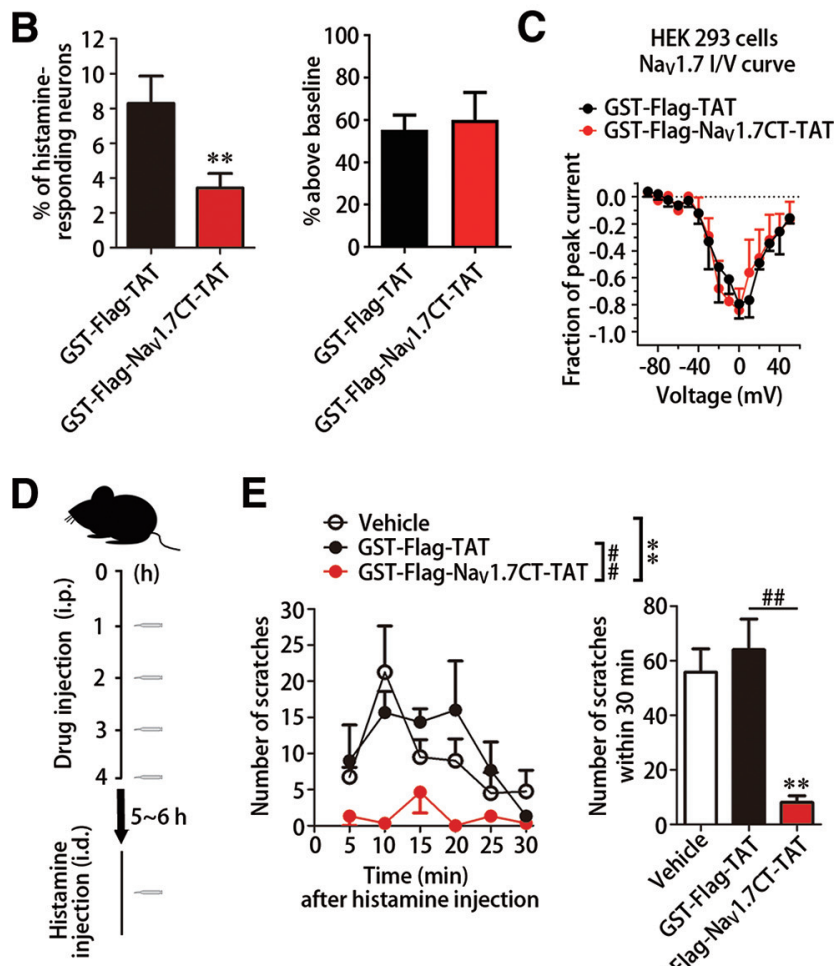

E

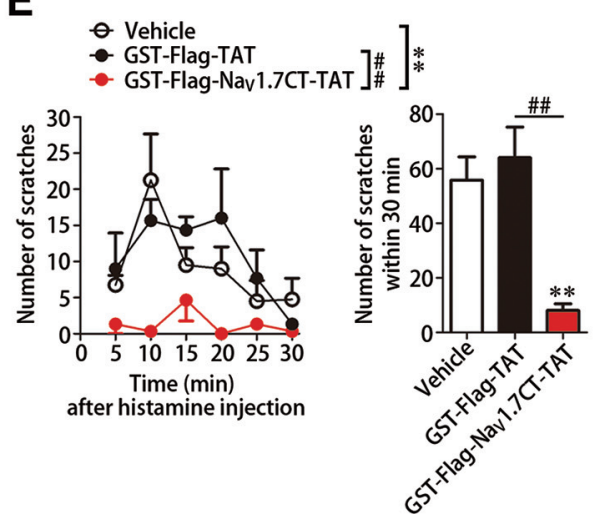

Figure 6. FGF13/Nav1.7 interaction is vital for histamine-induced itch. $A$, Coimmunoprecipitation was performed with protein extracts from cultured neurons with or without 5 min histamine incubation using FGF13 antibody or control lgG. Immunoblots and quantitative data showed that the level of FGF13 interacted with Nay 1.7 was significantly increased after 5 min $1 \mathrm{~mm}$ histamine incubation $(n=6) . * p<0.05$ versus without histamine incubation. $\boldsymbol{B}$, Calcium imaging showing reduced percentage of neurons responding to $1 \mathrm{~mm}$ histamine treated with GST-Flag-Nay 1.7CT-TAT ( $n=4$, from 1 or 2 mice each, 428 cells), compared with GST-Flag-TAT ( $n=4$ from 1 or 2 mice each, 509 cells). Data are mean \pm SEM. $* * p<0.01$ versus GST-Flag-TAT. C, Normalized I/N plots from recordings showing no significant change of Nay 1.7 currents in HEK293 cells expressing Nay 1.7 treated with GSTFlag-TAT and Nav1.7CT-TAT. D, Schematic illustration of the experiment conducted for the scratching behavior tests. Mice were intraperitoneally injected with the dose of $60 \mathrm{mg} / \mathrm{kg}$ GST-Flag-TAT, Nav1.7CT-TAT, or vehicle at $1 \mathrm{~h}$ intervals 4 times. Then, the mice were intradermally injected with $500 \mu \mathrm{g} / 50 \mu \mathrm{l}$ histamine at 5-6 h after last injection. The scratching behavior was immediately recorded. $\boldsymbol{E}$, The behavior test showing the reduced scratching number induced by histamine in mice treated with GST-Flag-Nay 1.7CT-TAT $(n=3)$, compared with mice treated with GST-Flag-TAT $(n=3)$ or vehicle $(n=4)$. Data are mean \pm SEM. $* * p<0.01$ versus vehicle. ${ }^{\# \#} p<0.01$ versus indicated.

evoked by a step depolarization $(-90 \mathrm{mV}$ to $50 \mathrm{mV}$ in $10 \mathrm{mV}$ increments) in HEK293 cells transfected with $\mathrm{Na}_{\mathrm{V}}$ 1.7. The I/V curves did not display significant difference in $\mathrm{Na}_{\mathrm{V}} 1.7$ currents of HEK293 cells treated with GST-Flag-TAT and Na $1.7 \mathrm{CT}$ TAT $\left(F_{(1,4)}=0.0138, p=0.9121\right.$; Fig. $\left.6 C\right)$. Thus, the FGF13/ $\mathrm{Na}_{\mathrm{V}} 1.7$ interaction is the necessity of mediating neuronal excitation in response to histamine. 
Finally, we evaluated the effect of disrupting interaction between FGF13 and $\mathrm{Na}_{\mathrm{V}} 1.7$ on the histamine-induced scratching behavior according to our previous report (L. Yang et al., 2017). The mice were intraperitoneally injected with the dose of $60 \mathrm{mg} /$ $\mathrm{kg}$ at $1 \mathrm{~h}$ intervals 4 times and examined scratching behavior in response to histamine at 5-6 h after the last injection (Fig. 6D). Mice treated with $\mathrm{Na}_{\mathrm{V}}$ 1.7CT-TAT displayed very limited $\left(F_{(2,35)}\right.$ $=11.790, p=0.0057)$ scratching number after histamine injection (Fig. 6E). The total number of scratching bouts induced by $500 \mu \mathrm{g}$ histamine was $64.0 \pm 11.2$ in mice $(n=3)$ injected with GST-Flag-TAT and $8.0 \pm 2.5$ in mice $(n=3)$ injected with $\mathrm{Na}_{\mathrm{V}}$ 1.7CT-TAT (Fig. $6 E ; t=4.862, \mathrm{df}=4, p=0.0083$ ). These data indicate that FGF13 is indispensable for itch-induced scratching behavior by interaction with $\mathrm{Na}_{\mathrm{V}} 1.7$.

\section{FGF13 is involved in 5-HT or CQ-induced scratching behavior, and chronic itch}

We further explored whether FGF13 was involved in the scratching behavior induced by other pruritogens, including 5-HT and CQ, an MrgprA3 agonist. In response to intradermal injection of $10 \mu \mathrm{g} 5$-HT in $50 \mu \mathrm{l}$, control $\mathrm{Fgfl} 3^{\mathrm{F} / \mathrm{Y}}$ mice reached a scratching peak at $10 \mathrm{~min}$ (Fig. $7 \mathrm{~A}$ ). At the same time, $\mathrm{Fgfl} 3^{-/ \mathrm{Y}}$ mice did not exhibit the scratching behavior induced by $5-\mathrm{HT}$ before $10 \mathrm{~min}$ and only showed a delayed onset of scratch between 15-20 min, which could be the off-target effect to activate glia cells or mast cells (De-Miguel et al., 2015), similar to histamine. Compared with $\mathrm{Fgfl} 3^{\mathrm{F} / \mathrm{Y}}$ mice with high scratching response, $\mathrm{Fg} f 13^{-/ \mathrm{Y}}$ mice displayed a limited number of scratches throughout $30 \mathrm{~min}$ after intradermal injection of $10 \mu \mathrm{g} / 50 \mu \mathrm{l} 5$-HT (Fig. $7 A ; F_{(1,61)}=$ 28.410, $p<0.0001)$. The total number of scratching bouts induced by 5 -HT was also highly decreased in $\mathrm{Fg} 13^{-/ \mathrm{Y}}$ mice $(20.4 \pm 5.4, n=32)$ compared with $\mathrm{Fgfl} 3^{\mathrm{F} / \mathrm{Y}}$ mice $(75.9 \pm 9.0$, $n=31$ ) (Fig. $7 A ; t=5.327, \mathrm{df}=61, p<0.0001$ ). Meanwhile, in response to intradermal injection of $200 \mu \mathrm{g}$ CQ in $50 \mu \mathrm{l}, \mathrm{Fg} f 13^{-/ Y}$ mice showed a decreased scratching throughout $30 \mathrm{~min}$ compared with $F g f 13^{\mathrm{F} / \mathrm{Y}}$ mice (Fig. $7 B ; F_{(1,55)}=4.287, p=0.0431$ ). The total number of scratching bouts induced by $\mathrm{CQ}$ was reduced in $\mathrm{Fg} 13^{-/ \mathrm{Y}}$ mice $(71.4 \pm 11.0, n=30)$ compared with Fgf $13^{\mathrm{F} / \mathrm{Y}}$ mice $(104.2 \pm 11.4, n=27$ ) (Fig. $7 B ; t=2.069, \mathrm{df}=55$, $p=0.0430)$. Furthermore, calcium imaging showed that the percentage of 5-HT-responding DRG neurons was significantly decreased in $\mathrm{Fg} 13^{-/ \mathrm{Y}}$ mice (Fig. $7 \mathrm{C}$; 5-HT: $7.1 \pm 1.0 \%$ for $\mathrm{Fg} 13^{\mathrm{F} / \mathrm{Y}}$ and $2.9 \pm 1.0 \%$ for $\left.F g f 13^{-Y Y}, t=13.500, \mathrm{df}=3, p=0.0009\right)$. However, the percentage of CQ-responding neurons was not significantly reduced (Fig. $7 C ; 21.1 \pm 4.1 \%$ for $F g f 13^{\mathrm{F} / \mathrm{Y}}$ and $16.2 \pm 3.2 \%$ for $\left.F g f 13^{-/ Y}, t=1.777, \mathrm{df}=7, p=0.1200\right)$. Both the behavioral and calcium imaging results suggest that the defect in 5 -HT response is larger than that of CQ in $F g f 13^{-/ Y}$ mice. Thus, the scratching behavior induced by $5-\mathrm{HT}$ and other pruritogens could also be impaired by FGF13 deficiency.

We also generated the DNFB-induced allergic contact dermatitis to examine the role of FGF13 in the chronic itch. After sensitization on the abdomen area by $50 \mu$ intradermal injection of $0.5 \%$ DNFB followed immediately by $100 \mu \mathrm{l}$ painting for $5 \mathrm{~d}$, $50 \mu \mathrm{l}$ of $0.2 \%$ DNFB was painted on the nape of neck area for challenge and the scratching bouts $24 \mathrm{~h}$ after each challenge was recorded for $1 \mathrm{~h}$ at day $6,8,10$, and $12 . \mathrm{Fg} 13^{\mathrm{F} / \mathrm{Y}}$ mice displayed a robust and persistent scratching behavior, which prolonged at day 12, while $F g f 13^{-/ Y}$ mice sustained at a significantly lower level of scratching behavior (Fig. $7 D ; F_{(1,13)}=14.80, p=0.0020$ ), suggesting FGF13 as an important mediator in chronic itch.

Additionally, we detected the algogen-induced behavior in FGF13-deficient mice. The TRPV1 has been shown to be involved in histamine-induced scratching by activation of H1R (Shim et al., 2007). Upon $10 \mu \mathrm{l}$ hindpaw injection of $0.1 \%$ capsaicin, a TRPV1 agonist, the number of flinches in $\mathrm{Fg} 13^{-/ Y}$ mice $(5.3 \pm 2.0, n=3)$ was significantly decreased compared with that in $F g f 13^{\mathrm{F} / \mathrm{Y}}$ mice $(29.4 \pm 3.3, n=5$ ) (Fig. $7 E ; t=5.212, \mathrm{df}=6$, $p=0.0020)$. Moreover, the transient receptor potential ankyrin 1 (TRPA1) was indicated as an essential component of MrgprA3mediated signaling (Wilson et al., 2011). In response to $10 \mu \mathrm{l}$ hindpaw injection of $2 \%$ AITC, a TRPA1 agonist, the flinches were not significantly altered between $\mathrm{Fg} 13^{\mathrm{F} / \mathrm{Y}}(35.7 \pm 10.4$, $n=6)$ and $F g f 13^{-/ Y}$ mice $(23.7 \pm 5.1, n=6)$ (Fig. $7 F ; t=1.034$, $\mathrm{df}=10, p=0.3260)$. Thus, TRPV1-mediated behavior is largely defective in FGF13-deficient mice.

\section{Discussion}

The present study demonstrates that FGF13 is required in histamine-induced itch sensation via interacting with $\mathrm{Na}_{\mathrm{V}}$ 1.7. Under normal condition, histamine activates small DRG neurons that express H1R. In the presence of FGF13, activation of H1R leads to subsequent activation of $\mathrm{Na}_{\mathrm{V}} 1.7$, AP firing, and scratching behavior. Loss of FGF13 causes a reduction in neuronal excitation and scratching behavior evoked by histamine. Consistently, disrupting the FGF13/ $\mathrm{Na}_{\mathrm{V}} 1.7$ interaction reduces the histamineevoked neuronal excitation and, most importantly, impairs scratching behavior. Moreover, loss of FGF13 also significantly impairs 5-HT-induced scratching behavior and DNFB-induced chronic itch. These findings indicate a new role of FGF13 in the itch sensation, which may provide a fresh therapeutic target for intervention of pathologic itch.

\section{FGF13 is vital for itch sensation}

FGF13 is widely distributed in the developing brain and has been implicated in neurobiological diseases. In human beings, Fgf13 mutation could cause X-linked intelligence disability and genetic epilepsy and febrile seizures plus (Puranam et al., 2015; Skare et al., 2018). Mice lacking Fgf13 have defects in neuronal migration and exhibit weakened learning and memory (Wu et al., 2012). FGF13 also maintains high-level expression in the DRG from development to adulthood. Both pain and itch are initiated and modulated by small DRG neurons (Ikoma et al., 2003). The majority of itch-sensitive neurons marked by $N p p b$ or MrgprA3 belong to $\mathrm{C} 2$ and $\mathrm{C} 4$ types of small DRG neurons. We previously reported that mice lacking FGF13 in small DRG neurons lost responsiveness to noxious heat. Heat nociception elicits a quick withdrawal behavior to avoid noxious heat stimuli, while the response of itch is to scratch. Since immunostaining reveals that FGF13 is present in $>80 \%$ of small DRG neurons (L. Yang et al., 2017), including C2 and C4 types, it is not surprising to find that FGF13 is also responsible for itch sensation. The present study showed that itch behavior induced by histamine was strongly reduced in mice lacking FGF13 in small DRG neurons. Histamine excites sensory neurons via its receptors and eventually evokes AP firing. Consistently, calcium imaging showed that the percentage of histamine-responding neurons were largely reduced in cultured small DRG neurons from $F g f 13^{-/ Y}$ mice. Moreover, the percentage of neurons with AP firing evoked by histamine was also extremely low in $\mathrm{Fg} 13^{-/ \mathrm{Y}}$ mice compared with $\mathrm{Fg} f 3^{\mathrm{F} / \mathrm{Y}}$ mice. These evidences support that FGF13 is a key molecule involved in the histamine-evoked itch sensation.

Further detection of itch behavior induced by $5-\mathrm{HT}$ also displayed an impairment of scratching behavior in FGF13-deficient mice, suggesting that FGF13 mediates both histamine-dependent 
A

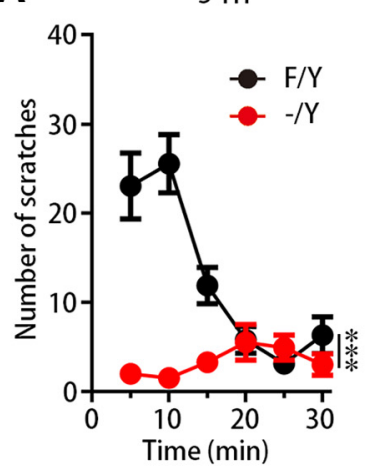

B

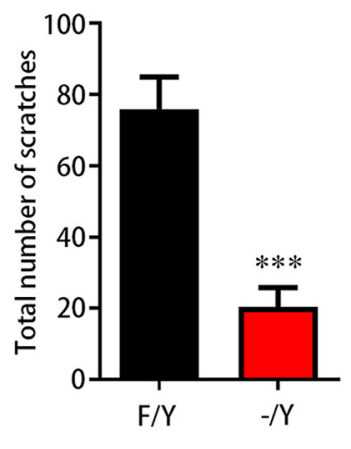

CQ

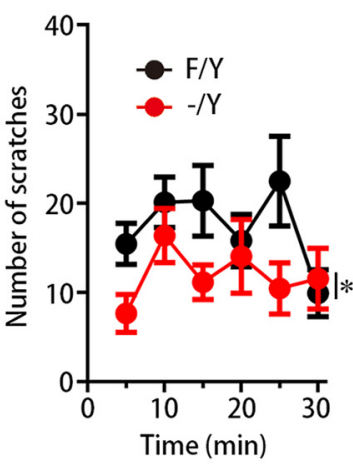

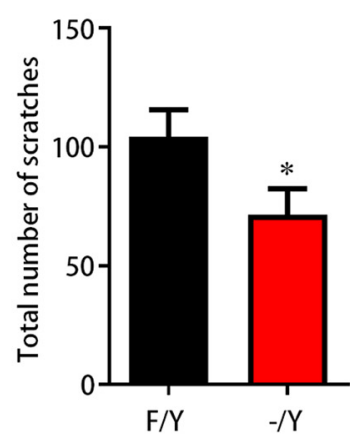

C
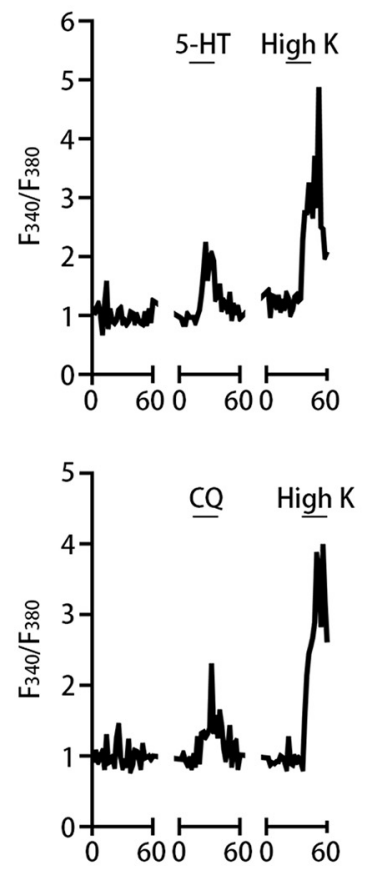

D

(day)

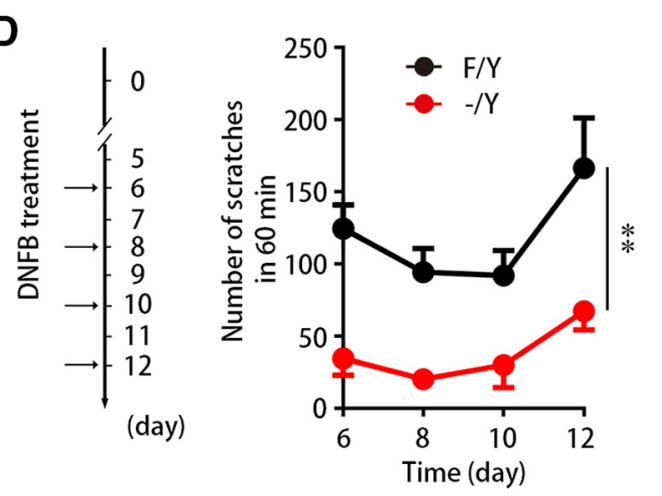

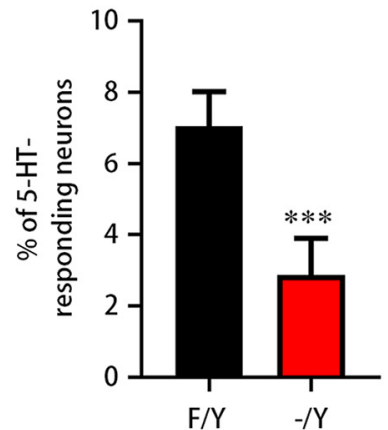

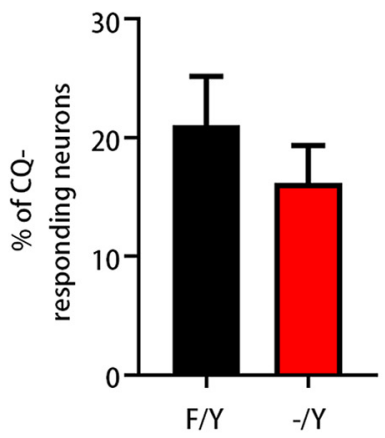

E
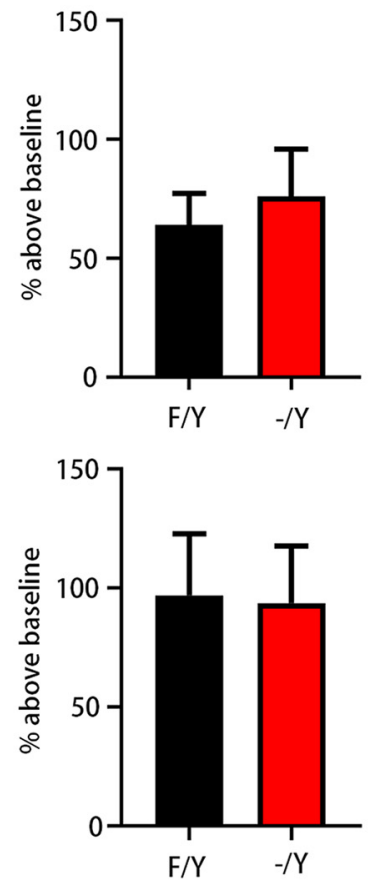
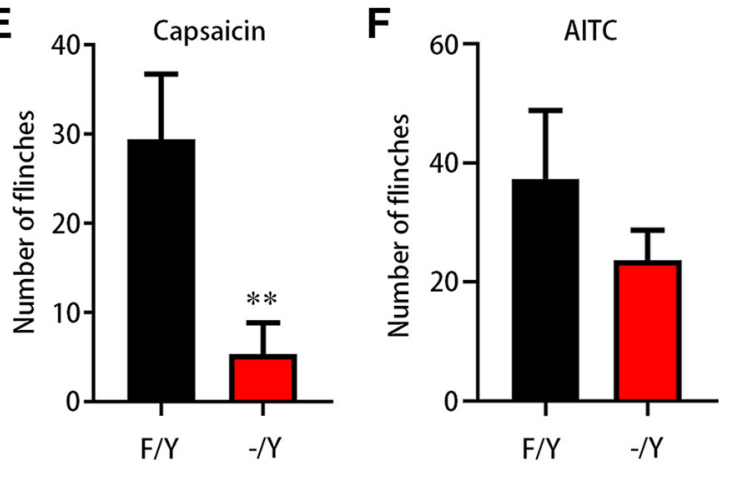

Figure 7. FGF13 participates in other types of itch. $\boldsymbol{A}, \boldsymbol{B}$, The behavior test showing altered scratching number induced by 5 -HT and $\mathrm{CQ}$ in FGF13-deficient mice. The scratching number

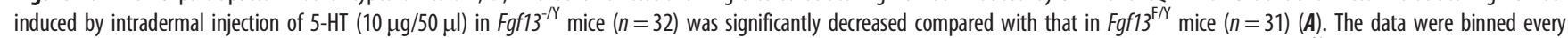
$5 \mathrm{~min}$ (left) and analyzed during $30 \mathrm{~min}$ (right). The total scratching bouts induced by CQ (bottom right) were also significantly reduced (bottom right) in Fgf $13^{-N}$ mice $(n=30)$ compared with $\mathrm{Fgfl}^{\mathrm{FN}}$ mice $(n=27)(\boldsymbol{B})$. C, Calcium imaging showing the neuronal responses to 5 -HT or $\mathrm{CQ}$ in $\mathrm{Fgf13}{ }^{-N}$ mice. Left, Representative trace from neurons responding to $5-\mathrm{HT}$ or $\mathrm{CQ}$ in calcium imaging. The response to $\mathrm{KCl}$ indicates the normal activity of a neuron. The percentage of 5 -HT-responding neurons was reduced significantly in Fgf $13^{-N}$ mice $(n=4$ from 1 or 2 mice each, 214 cells), compared with $F g f 13^{\mathrm{FN}}$ mice ( $n=4$ from 1 or 2 mice each, 286 cells). The percentage of neurons responding to CQ was not significantly reduced in $\mathrm{Fgf1} 13^{-N}$ mice (middle). The magnitude of the $\mathrm{Ca}^{2+}$ response (right) evoked by $5-\mathrm{HT}$ or $\mathrm{CQ}$ remained unaltered in neurons from $\mathrm{Fgf13} 3^{\mathrm{FN}}$ and $\mathrm{Fgf13} 3^{-N}$ mice (right). D, The behavior test showing significantly decreased scratching number in $F g f 13^{-N}$ mice $(n=6)$ in the chronic itch model induced by DNFB at day $6,8,10$, and 12 compared with $F g f 13^{\mathrm{FN}}$ mice $(n=9)$. $\boldsymbol{E}$, The flinching behavior following capsaicin injection was significantly reduced in $F g f 13^{-N}$ mice. $\boldsymbol{F}$, The flinching behavior after AITC injection remained unaltered in Fgf $13^{-N}$ mice. Data are mean \pm SEM. $* p<0.05 ; * * p<0.01$; $* * * p<0.001$; versus Fgf13 ${ }^{-N}$ mice. 
and histamine-independent itch. However, the defective level of itch induced by various pruritogens is not equal in $\mathrm{Fg} / 13^{-/ Y}$ mice showing almost absent scratching in response to histamine and 5-HT but only reduced scratching bouts induced by CQ. This phenomenon is also observed in DRG neurons, in which the percentage of histamine or 5-HT-responding DRG neurons was largely decreased but the percentage of CQresponding DRG neurons was not significantly reduced in $\mathrm{Fgfl3}^{-/ \mathrm{Y}}$ mice. In humans, both histamine and 5-HT are linked to itch in allergic contact dermatitis. Substantially, $\mathrm{Fgfl3}^{-/ Y}$ mice exhibited a great decline of scratching behavior in DNFB-induced allergic contact dermatitis. This evidence suggests that FGF13 is involved in chronic itch participated by histamine and $5-\mathrm{HT}$.

\section{FGF13 interacts with $\mathrm{Na}_{\mathrm{V}} 1.7$ to mediate itch sensation}

Intradermal injection of histamine notably induces vigorous scratching behavior in both humans and mice. Generally, histamine first initiates the intracellular signaling by combining with its receptors, subsequently activates voltage-gated ion channels, and eventually induces AP firing and itch-evoked scratching behavior. H1R, one of four known histamine receptors, has been studied most extensively in the context of histamine-induced itch. Our finding also supports that H1R is the main receptor mediating histamine signaling in itch sensation. First, analysis of our single-cell RNA sequencing showed that, unlike $\mathrm{H} 4 \mathrm{R}$, three types of histamine receptors $(\mathrm{H} 1 \mathrm{R}, \mathrm{H} 2 \mathrm{R}$, and H3R) were detected in DRG neurons. Then, we transfected all four types of histamine receptors into DRG neurons, respectively, and only found that the percentage of histamine-responding neurons was significantly increased after the H1R transfection. Moreover, total scratching bouts induced by intradermal injection of dimaprit (H2R agonist), immethridine (standard H3R agonist), or clobenpropit (H3R antagonist and H4R agonist) were not significantly changed between $\mathrm{Fgfl} 3^{\mathrm{F} / \mathrm{Y}}$ and $\mathrm{Fgfl} \mathrm{3}^{-/ \mathrm{Y}}$ mice, excluding the involvement of these three receptors in FGF13-mediated pathway of itch behavior. However, the interaction between FGF13 and H1R was not detected in the coimmunoprecipitation experiment, and FGF13 did not promote $\mathrm{Ca}^{2+}$ signals in HEK293 cells coexpressing H1R. Therefore, the defected neuronal response and itch behavior induced by histamine in FGF13deficient mice are not because of loss of FGF13 effect on H1R function.

$\mathrm{Na}_{V}$ channels are critical for the generation and propagation of APs. Of the nine $\alpha$-subunits of $\mathrm{Na}_{\mathrm{V}}$ channels, $\mathrm{Na}_{V} 1.6, \mathrm{Na}_{V} 1.7$, $\mathrm{Na}_{\mathrm{V}} 1.8$, and $\mathrm{Na}_{\mathrm{V}} 1.9$ are expressed in DRG neurons and contribute to somatosensory transmission. Intracellular, nonsecretory forms of FGFs are essential regulators of neuronal excitability and interact with the cytoplasmic carboxy terminal tail of $\alpha$-subunits. $\mathrm{Na}_{\mathrm{V}} 1.7$ has been strongly implicated in human pain sensation, based on the studies with human gain-of-function and lossof-function mutations (Y. Yang et al., 2004; Dib-Hajj et al., 2005; Cox et al., 2006; Fertleman et al., 2006; Emery et al., 2015). A recent report showed that gain-of-function mutation of $\mathrm{Na}_{\mathrm{V}} 1.7$ caused paroxysmal itch in patients (Devigili et al., 2014). In mice, selective $\mathrm{Na}_{\mathrm{V}} 1.7$ inhibitors suppressed itch behaviors induced by histamine (Graceffa et al., 2017; Chandra et al., 2020). Na 1.7 $\mathrm{KO}$ mice in which the functional expression of $\mathrm{Na}_{\mathrm{V}} 1.7$ being prevented in DRG and trigeminal ganglia neurons exhibited strong scratching reduction toward many pruritogens, such as C48/80, 5-HT, CQ, endothelin, and histamine (Kühn et al., 2020). Particularly, a tamoxifen-inducible $\mathrm{Na}_{\mathrm{V}} 1.7 \mathrm{KO}$ mouse allowing adult-onset deletion of SCN9A-encoding $\mathrm{Na}_{\mathrm{V}} 1.7$ also appeared lack of scratching behavior induced by histamine (Flinspach et al., 2017). Our patch-clamp recording also detected that the percentage of AP firing was significantly reduced by blocking $\mathrm{Na}_{\mathrm{V}} 1.7$ in DRG neurons expressing H1R, further supporting that $\mathrm{Na}_{\mathrm{V}} 1.7$ acts on the neural circuit of itch sensation.

Our previous results showed that FGF13 was coexpressed with the majority of neurons expressing $\mathrm{Na}_{V} 1.7$ and exhibited strong interaction with $\mathrm{Na}_{\mathrm{V}} 1.7$. Moreover, FGF13 could also regulate the function of $\mathrm{Na}_{\mathrm{V}} 1.7$ by increasing its current density (L. Yang et al., 2017). This evidence implies a functional role of $\mathrm{Na}_{\mathrm{V}} 1.7$ in FGF13-mediated itch sensation. Our biochemical results showed that the FGF13/Nav 1.7 interaction level was enhanced by 5 min histamine treatment in cultured DRG neurons. After disrupting the interaction between FGF13 and $\mathrm{Na}_{\mathrm{V}} 1.7$, the $\mathrm{Ca}^{2+}$ signals evoked by histamine were significantly attenuated in DRG neurons. Consistently, the scratching behavior induced by histamine was also impaired greatly by the disruption of FGF13/ $\mathrm{Na}_{V} 1.7$ interaction. However, unlike the response to heat, the plasma-membrane level of $\mathrm{Na}_{\mathrm{V}} 1.7$ in FGF13-deficient DRG neurons induced by shFGF13 was not significantly reduced after histamine treatment (data not shown), which suggests a different molecular mechanism underlying the role of FGF13 in regulating $\mathrm{Na}_{\mathrm{V}} 1.7$ function in the histamine signaling. Therefore, FGF13 interacting with $\mathrm{Na}_{\mathrm{V}} 1.7$ is proved as the key process mediating the histamineevoked neuronal signaling and, more importantly, the histamine-induced itch behavior.

Previous studies report that TRPV1 is a primary transducer of histamine-evoked itch (Shim et al., 2007; Imamachi et al., 2009). Our previous study using the patch-clamp recording showed that the amplitude of capsaicin-induced currents was not reduced but significantly increased in FGF13-deficient DRG neurons (L. Yang et al., 2017), implying the intact of TRPV1 function. However, in the present study, the paw licking response induced by capsaicin was largely reduced in $\mathrm{Fg} 13^{-/ Y}$ mice, suggesting the defect of TRPV1 downstream effectors in DRG neurons. A previous study showed that, after selectively inhibiting $\mathrm{Na}_{\mathrm{V}} 1.7$ with sulfonamides, the total amount of licking time was significantly reduced following intraplantar injection of capsaicin (Graceffa et al., 2017). Therefore, the defect of capsaicin-induced behavior in $\mathrm{Fgfl} 3^{-/ \mathrm{Y}}$ mice may also result from the functional reduction of $\mathrm{Na}_{\mathrm{V}} 1.7$, a key downstream effector of TRPV1 activation. Moreover, the flinching behavior induced by AITC was not significantly changed in $\mathrm{Fg} f 13^{-/ Y}$ mice, suggesting the presence of a TRPA1-mediated pathway. Previous studies report that TRPA1 is required for 5-HT-induced itch (Morita et al., 2015). Differences in the defects of scratching behavior induced by histamine, 5-HT, and CQ in FGF13-deficient mice suggest that FGF13 may involve differentially in the signaling processes.

\section{References}

Agarwal N, Offermanns S, Kuner R (2004) Conditional gene deletion in primary nociceptive neurons of trigeminal ganglia and dorsal root ganglia. Genesis 38:122-129.

Baroody FM, Foster KA, Markaryan A, deTineo M, Naclerio RM (2008) Nasal ocular reflexes and eye symptoms in patients with allergic rhinitis. Ann Allergy Asthma Immunol 100:194-199.

Bell JK, McQueen DS, Rees JL (2004) Involvement of histamine H4 and H1 receptors in scratching induced by histamine receptor agonists in BalbC mice. Br J Pharmacol 142:374-380. 
Bosch MK, Carrasquillo Y, Ransdell JL, Kanakamedala A, Ornitz DM, Nerbonne JM (2015) Intracellular FGF14 (iFGF14) is required for spontaneous and evoked firing in cerebellar Purkinje neurons and for motor coordination and balance. J Neurosci 35:6752-6769.

Chandra S, Wang Z, Tao X, Chen O, Luo X, Ji RR, Bortsov AV (2020) Computer-aided discovery of a new $\mathrm{Na}_{\mathrm{V}} 1.7$ inhibitor for treatment of pain and itch. Anesthesiology 133:611-627.

Cox JJ, Reimann F, Nicholas AK, Thornton G, Roberts E, Springell K, Karbani G, Jafri H, Mannan J, Raashid Y, Al-Gazali L, Hamamy H, Valente EM, Gorman S, Williams R, McHale DP, Wood JN, Gribble FM, Woods CG (2006) An SCN9A channelopathy causes congenital inability to experience pain. Nature 444:894-898.

De-Miguel FF, Leon-Pinzon C, Noguez P, Mendez B (2015) Serotonin release from the neuronal cell body and its long-lasting effects on the nervous system. Philos Trans R Soc Lond B Biol Sci 370:20140196.

Devigili G, Eleopra R, Pierro T, Lombardi R, Rinaldo S, Lettieri C, Faber CG, Merkies IS, Waxman SG, Lauria G (2014) Paroxysmal itch caused by gain-of-function $\mathrm{Na}_{\mathrm{V}} 1.7$ mutation. Pain 155:1702-1707.

Dib-Hajj SD, Rush AM, Cummins TR, Hisama FM, Novella S, Tyrrell L, Marshall L, Waxman SG (2005) Gain-of-function mutation in $\mathrm{Na}_{\mathrm{V}} 1.7$ in familial erythromelalgia induces bursting of sensory neurons. Brain 128:1847-1854.

Dong X, Dong X (2018) Peripheral and central mechanisms of itch. Neuron 98:482-494.

Emery EC, Habib AM, Cox JJ, Nicholas AK, Gribble FM, Woods CG, Reimann F (2015) Novel SCN9A mutations underlying extreme pain phenotypes: unexpected electrophysiological and clinical phenotype correlations. J Neurosci 35:7674-7681.

Fertleman CR, Baker MD, Parker KA, Moffatt S, Elmslie FV, Abrahamsen B, Ostman J, Klugbauer N, Wood JN, Gardiner RM, Rees M (2006) SCN9A mutations in paroxysmal extreme pain disorder: allelic variants underlie distinct channel defects and phenotypes. Neuron 52:767-774.

Flinspach M, Xu Q, Piekarz AD, Fellows R, Hagan R, Gibbs A, Liu Y, Neff RA, Freedman J, Eckert WA, Zhou M, Bonesteel R, Pennington MW, Eddinger KA, Yaksh TL, Hunter M, Swanson RV, Wickenden AD (2017) Insensitivity to pain induced by a potent selective closed-state $\mathrm{Na}_{\mathrm{v}} 1.7$ inhibitor. Sci Rep 7:39662.

Graceffa RF, Boezio AA, Able J, Altmann S, Berry LM, Boezio C, Butler JR, Chu-Moyer M, Cooke M, DiMauro EF, Dineen TA, Feric Bojic E, Foti RS, Fremeau RT, Guzman-Perez A, Gao H, Gunaydin H, Huang H, Huang L, Ilch C, et al. (2017) Sulfonamides as selective $\mathrm{Na}_{\mathrm{V}} 1.7$ inhibitors: optimizing potency, pharmacokinetics, and metabolic properties to obtain atropisomeric quinolinone (AM-0466) that affords robust in vivo activity. J Med Chem 60:5990-6017.

Han L, Ma C, Liu Q, Weng HJ, Cui Y, Tang Z, Kim Y, Nie H, Qu L, Patel KN, Li Z, McNeil B, He S, Guan Y, Xiao B, LaMotte RH, Dong X (2013) A subpopulation of nociceptors specifically linked to itch. Nat Neurosci 16:174-182.

Hartung H, Feldman B, Lovec H, Coulier F, Birnbaum D, Goldfarb M (1997) Murine FGF-12 and FGF-13: expression in embryonic nervous system, connective tissue and heart. Mech Dev 64:31-39.

Hide M, Francis DM, Grattan C, Hakimi J, Kochan JP, Greaves MW (1993) Autoantibodies against the high-affinity IgE receptor as a cause of histamine release in chronic urticaria. N Engl J Med 328:1599-1604.

Ikoma A, Rukwied R, Ständer S, Steinhoff M, Miyachi Y, Schmelz M (2003) Neuronal sensitization for histamine-induced itch in lesional skin of patients with atopic dermatitis. Arch Dermatol 139:1455-1458.

Imamachi N, Park GH, Lee H, Anderson DJ, Simon MI, Basbaum AI, Han SK (2009) TRPV1-expressing primary afferents generate behavioral responses to pruritogens via multiple mechanisms. Proc Natl Acad Sci USA 106:11330-11335.

Jin H, He R, Oyoshi M, Geha RS (2009) Animal models of atopic dermatitis. J Invest Dermatol 129:31-40.

Kornecook TJ, Yin R, Altmann S, Be X, Berry V, Ilch CP, Jarosh M, Johnson D, Lee JH, Lehto SG, Ligutti J, Liu D, Luther J, Matson D, Ortuno D, Roberts J, Taborn K, Wang J, Weiss MM, Yu V, et al. (2017) Pharmacologic characterization of AMG8379, a potent and selective small molecule sulfonamide antagonist of the voltage-gated sodium channel $\mathrm{Na}_{v}$ 1. 7. J Pharmacol Exp Ther 362:146-160.
Kühn H, Kappes L, Wolf K, Gebhardt L, Neurath MF, Reeh P, Fischer MJ, Kremer AE (2020) Complementary roles of murine $\mathrm{Na}_{\mathrm{V}} 1.7, \mathrm{Na}_{\mathrm{V}} 1.8$ and $\mathrm{Na}_{\mathrm{V}} 1.9$ in acute itch signalling. Sci Rep 10:2326.

Laezza F, Gerber BR, Lou JY, Kozel MA, Hartman H, Craig AM, Ornitz DM, Nerbonne JM (2007) The FGF14F145S mutation disrupts the interaction of FGF14 with voltage-gated $\mathrm{Na}^{+}$channels and impairs neuronal excitability. J Neurosci 27:12033-12044.

Laezza F, Lampert A, Kozel MA, Gerber BR, Rush AM, Nerbonne JM, Waxman SG, Dib-Hajj SD, Ornitz DM (2009) FGF14 N-terminal splice variants differentially modulate $\mathrm{Na}_{\mathrm{v}} 1.2$ and $\mathrm{Na}_{\mathrm{v}} 1$.6-encoded sodium channels. Mol Cell Neurosci 42:90-101.

Leonardi A (2002) The central role of conjunctival mast cells in the pathogenesis of ocular allergy. Curr Allergy Asthma Rep 2:325-331.

Li CL, Li KC, Wu D, Chen Y, Luo H, Zhao JR, Wang SS, Sun MM, Lu YJ, Zhong YQ, Hu XY, Hou R, Zhou BB, Bao L, Xiao HS, Zhang X (2016) Somatosensory neuron types identified by high-coverage single-cell RNA-sequencing and functional heterogeneity. Cell Res 26:83-102.

Li GD, Wo Y, Zhong MF, Zhang FX, Bao L, Lu YJ, Huang YD, Xiao HS, Zhang X (2002) Expression of fibroblast growth factors in rat dorsal root ganglion neurons and regulation after peripheral nerve injury. Neuroreport 13:1903-1907.

Liu CJ, Dib-Hajj SD, Waxman SG (2001) Fibroblast growth factor homologous factor $1 \mathrm{~B}$ binds to the $\mathrm{C}$ terminus of the tetrodotoxin-resistant sodium channel $\mathrm{rNa}_{\mathrm{v}} 1.9 \mathrm{a}(\mathrm{NaN})$. J Biol Chem 276:18925-18933.

Liu CJ, Dib-Hajj SD, Renganathan M, Cummins TR, Waxman SG (2003) Modulation of the cardiac sodium channel $\mathrm{Na}_{\mathrm{v}} 1.5$ by fibroblast growth factor homologous factor 1B. J Biol Chem 278:1029-1036.

Liu Q, Tang Z, Surdenikova L, Kim S, Patel KN, Kim A, Ru F, Guan Y, Weng HJ, Geng Y, Undem BJ, Kollarik M, Chen ZF, Anderson DJ, Dong X (2009) Sensory neuron-specific GPCR Mrgprs are itch receptors mediating chloroquine-induced pruritus. Cell 139:1353-1365.

Lou JY, Laezza F, Gerber BR, Xiao M, Yamada KA, Hartmann H, Craig AM, Nerbonne JM, Ornitz DM (2005) Fibroblast growth factor 14 is an intracellular modulator of voltage-gated sodium channels. J Physiol 569:179193.

Marx IE, Dineen TA, Able J, Bode C, Bregman H, Chu-Moyer M, DiMauro EF, Du B, Foti RS, Fremeau RT, Gao H, Gunaydin H, Hall BE, Huang L, Kornecook T, Kreiman CR, La DS, Ligutti J, Lin MJ, Liu D, et al. (2016) Sulfonamides as selective $\mathrm{Na}_{\mathrm{V}} 1.7$ inhibitors: optimizing potency and pharmacokinetics to enable in vivo target engagement. ACS Med Chem Lett 7:1062-1067.

Mishra SK, Hoon MA (2013) The cells and circuitry for itch responses in mice. Science 340:968-971.

Morita T, McClain SP, Batia LM, Pellegrino M, Wilson SR, Kienzler MA, Lyman K, Olsen AS, Wong JF, Stucky CL, Brem RB, Bautista DM (2015) HTR7 mediates serotonergic acute and chronic itch. Neuron 87:124-138

Puranam RS, He XP, Yao L, Le T, Jang W, Rehder CW, Lewis DV, McNamara JO (2015) Disruption of Fgf13 causes synaptic excitatory-inhibitory imbalance and genetic epilepsy and febrile seizures plus. J Neurosci 35:8866-8881.

Rausl A, Nordlind K, Wahlgren CF (2013) Pruritic and vascular responses induced by serotonin in patients with atopic dermatitis and in healthy controls. Acta Derm Venereol 93:277-280.

Rossbach K, Nassenstein C, Gschwandtner M, Schnell D, Sander K, Seifert R, Stark H, Kietzmann M, Baumer W (2011) Histamine H1, H3 and H4 receptors are involved in pruritus. Neuroscience 190:89-102.

Shim WS, Oh U (2008) Histamine-induced itch and its relationship with pain. Mol Pain 4:29.

Shim WS, Tak MH, Lee MH, Kim M, Kim M, Koo JY, Lee CH, Kim M, Oh U (2007) TRPV1 mediates histamine-induced itching via the activation of phospholipase A2 and 12-lipoxygenase. J Neurosci 27:2331-2337.

Skare Ø, Lie RT, Haaland ØA, Gjerdevik M, Romanowska J, Gjessing HK, Jugessur A (2018) Analysis of parent-of-origin effects on the X chromosome in Asian and European orofacial cleft triads identifies associations with DMD, FGF13, EGFL6. Front Genet 9:25.

Soga F, Katoh N, Inoue T, Kishimoto S (2007) Serotonin activates human monocytes and prevents apoptosis. J Invest Dermatol 127:1947-1955. 
Thurmond RL, Gelfand EW, Dunford PJ (2008) The role of histamine H1 and $\mathrm{H} 4$ receptors in allergic inflammation: the search for new antihistamines. Nat Rev Drug Discov 7:41-53.

Wilson SR, Gerhold KA, Bifolck-Fisher A, Liu Q, Patel KN, Dong X, Bautista DM (2011) TRPA1 is required for histamine-independent, Mas-related G protein-coupled receptor-mediated itch. Nat Neurosci 14:595-602.

Wu QF, Yang L, Li S, Wang Q, Yuan XB, Gao X, Bao L, Zhang X (2012) Fibroblast growth factor 13 is a microtubule-stabilizing protein regulating neuronal polarization and migration. Cell 149:1549-1564.

Yan H, Pablo JL, Wang C, Pitt GS (2014) FGF14 modulates resurgent sodium current in mouse cerebellar Purkinje neurons. Elife 3:e04193.
Yang L, Dong F, Yang Q, Yang PF, Wu R, Wu QF, Wu D, Li CL, Zhong YQ, Lu YJ, Cheng X, Xu FQ, Chen L, Bao L, Zhang X (2017) FGF13 selectively regulates heat nociception by interacting with $\mathrm{Na}_{\mathrm{v}} 1.7$. Neuron 93:806-821.

Yang Y, Wang Y, Li S, Xu Z, Li H, Ma L, Fan J, Bu D, Liu B, Fan Z, Wu G, Jin J, Ding B, Zhu X, Shen Y (2004) Mutations in SCN9A, encoding a sodium channel alpha subunit, in patients with primary erythermalgia. J Med Genet 41:171-174.

Zhang F, Wu Y, Xue S, Wang S, Zhang C, Cao Z (2019) 3'-OMethylorobol inhibits the voltage-gated sodium channel NaV1.7 with anti-itch efficacy in a histamine-dependent itch mouse model. Int J Mol Sci 20:6058. 